\title{
BIOLOGICAL DIVERSITY OF THREE VERTEBRATE GROUPS IN FIVE LANDSCAPES SUPPORTED BY THE WILDLIFE CONSERVATION SOCIETY IN THE ANDES-AMAZON
}

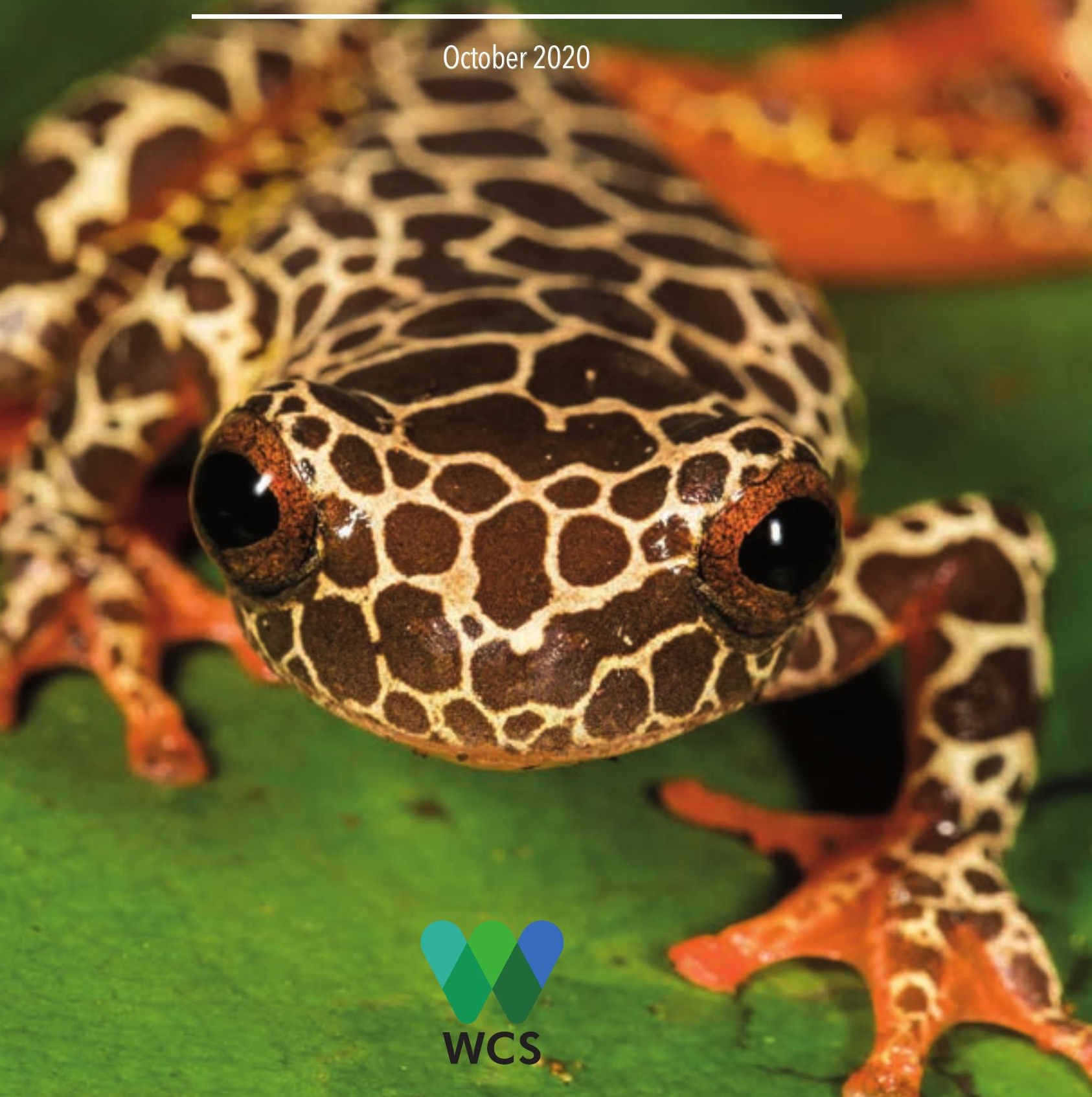




\section{BIOLOGICAL DIVERSITY OF THREE VERTEBRATE GROUPS IN FIVE LANDSCAPES SUPPORTED BY THE WILDLIFE CONSERVATION SOCIETY IN THE ANDES-AMAZON}

October 2020

Supproted by:

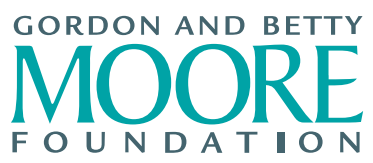


Credits:

Title: Biological diversity of three vertebrate groups in five landscapes supported by the Wildlife Conservation Society in the Andes-Amazon.

Edition: October 2020

Editor: Wildlife Conservation Society (WCS)

Technical writing:

PhD. Robert Wallace - Director, Greater Madidi-Tambopata Landscape Conservation Program, WCS Bolivia

MSc. Omar Torrico - Amazon Monitoring \& Climate Change Management, WCS Bolivia

Ing. Vladimir Paye - GIS \& Climate Change, WCS Bolivia

Cover photograph: Dendropsophus leucophyllatus-Robert Wallace/WCS

Design: Omar Torrico-WCS

For the production of these analyses we are especially grateful for the kind provision of species distribution data from the International Union for the Conservation of Nature (IUCN) Red List Data (Version 2019-1) for amphibians and mammals, and BirdLife International for birds. We would also like to acknowledge AmphibiaWeb and the South American Classification Committee for additional information on amphibians and birds, respectively. We are also grateful for the support of the Gordon and Betty Moore Foundation during the production of these analyses. Finally, we thank Carlos Rios, LeonorValenzuela, Germán Forero (WCS Colombia), Mariana Montoya, Armando Mercado, Luis Moya, Emiliana Isasi-Catalá (WCS Peru), Galo Zapata, Diana Paredes (WCS Ecuador), Carlos Durigan, Camila Ferrara, Camila Fagundes, Guillermo Estupiñan (WCS Brazil), Ariel Reinaga, Enrique Domic, Zulia Porcel and Nuria Bernal (WCS Bolivia), for providing systematized records of species distribution in the Andes-Amazon landscapes supported by WCS, and Padu Franco, Elvira Salinas, and Mariana Varese for revisions which improved the content of the publication.

Suggested citation: Wallace, R., 0. Torrico \& V. Paye. 2020. Biological diversity of three vertebrate groups in five landscapes supported by the Wildlife Conservation Society in the Andes-Amazon. Wildlife Conservation Society (WCS). Technical report. La Paz, Bolivia. 55 pp.

Legal deposit: 4-1-1578-20

ISBN: 978-99974-926-4-7

Printed in Bolivia 


\section{Content}

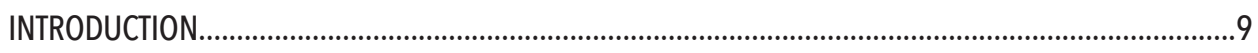

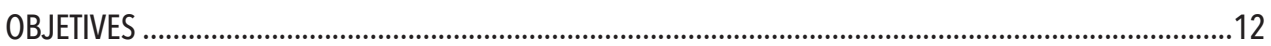

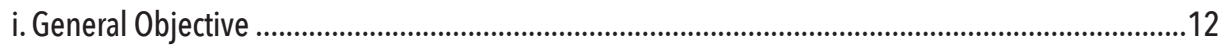

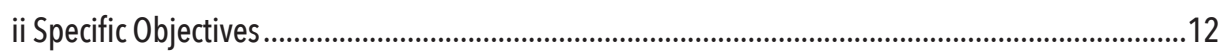

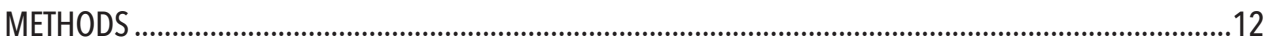

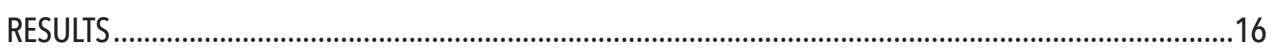

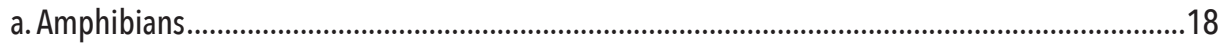

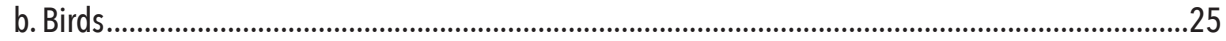

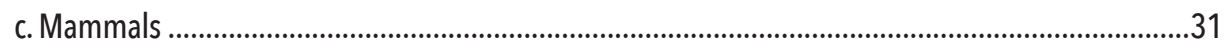

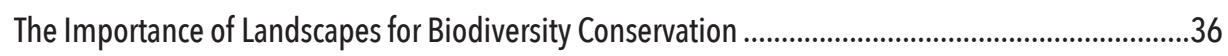

The Importance of Landscape Species in the Andes-Amazon .........................................................40

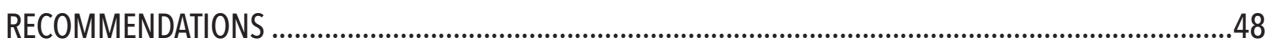

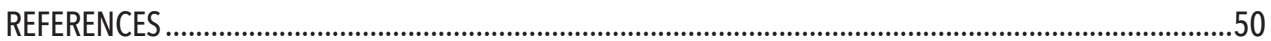




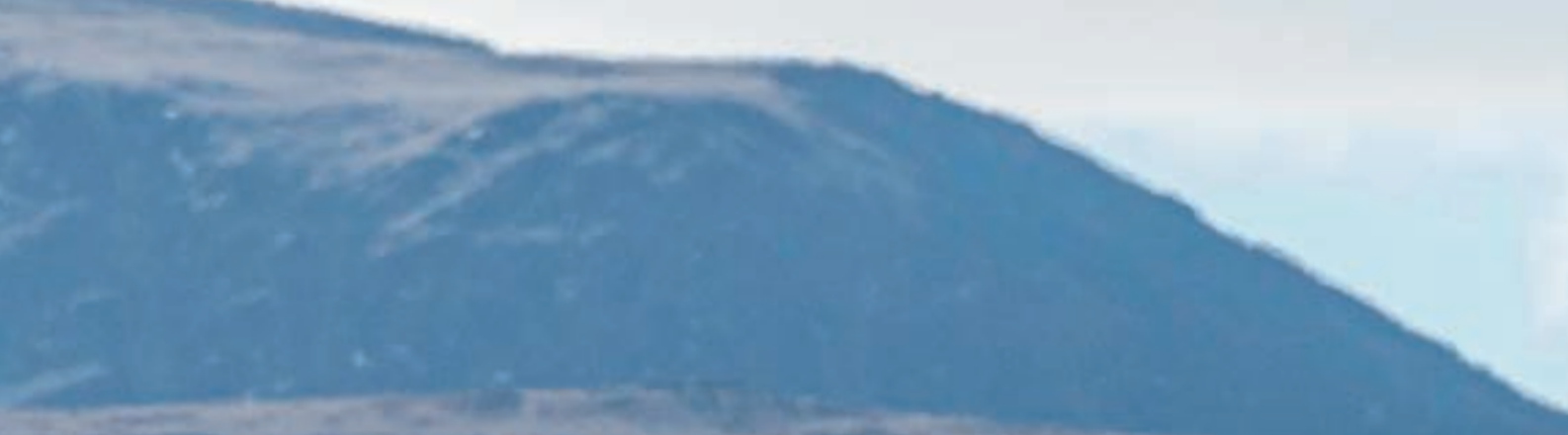

$=$

nowes

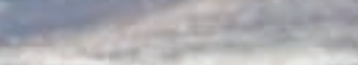

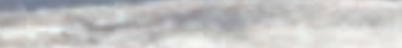

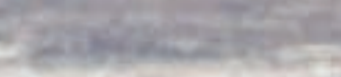

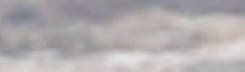

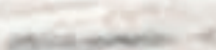

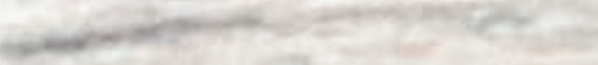

and

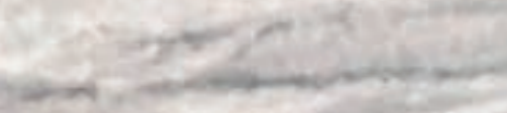

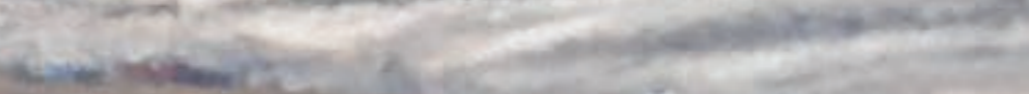

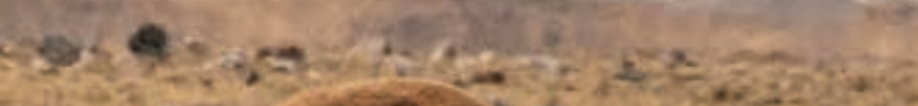

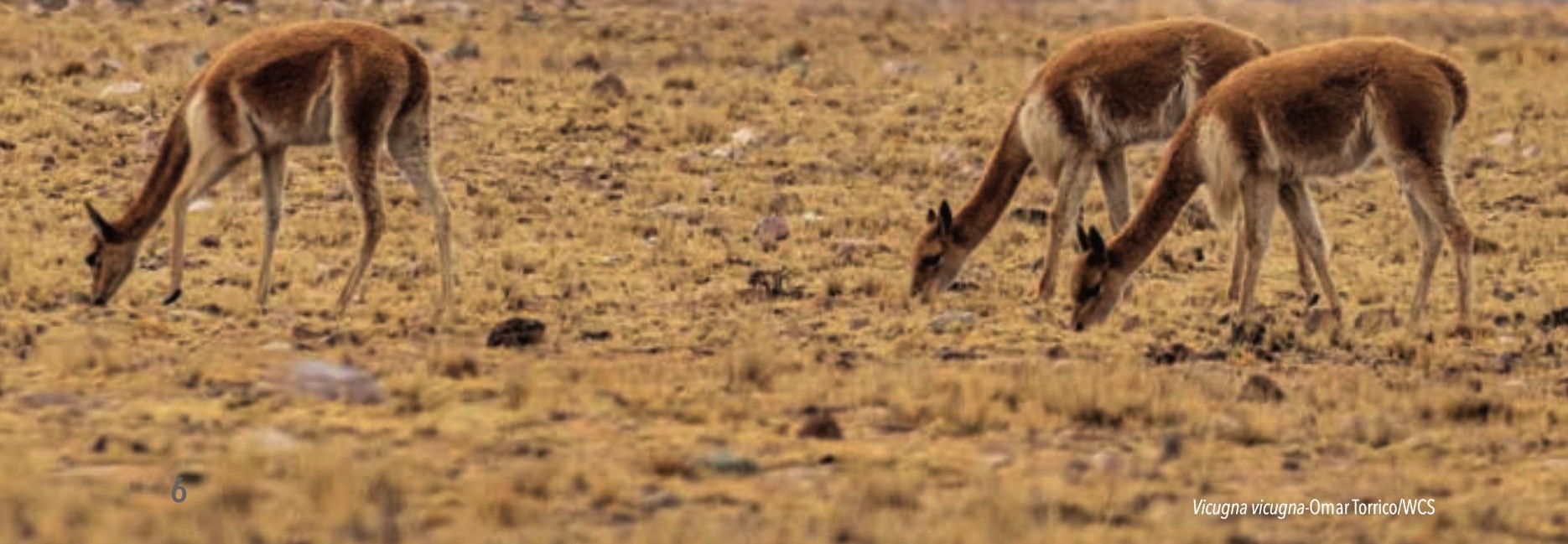




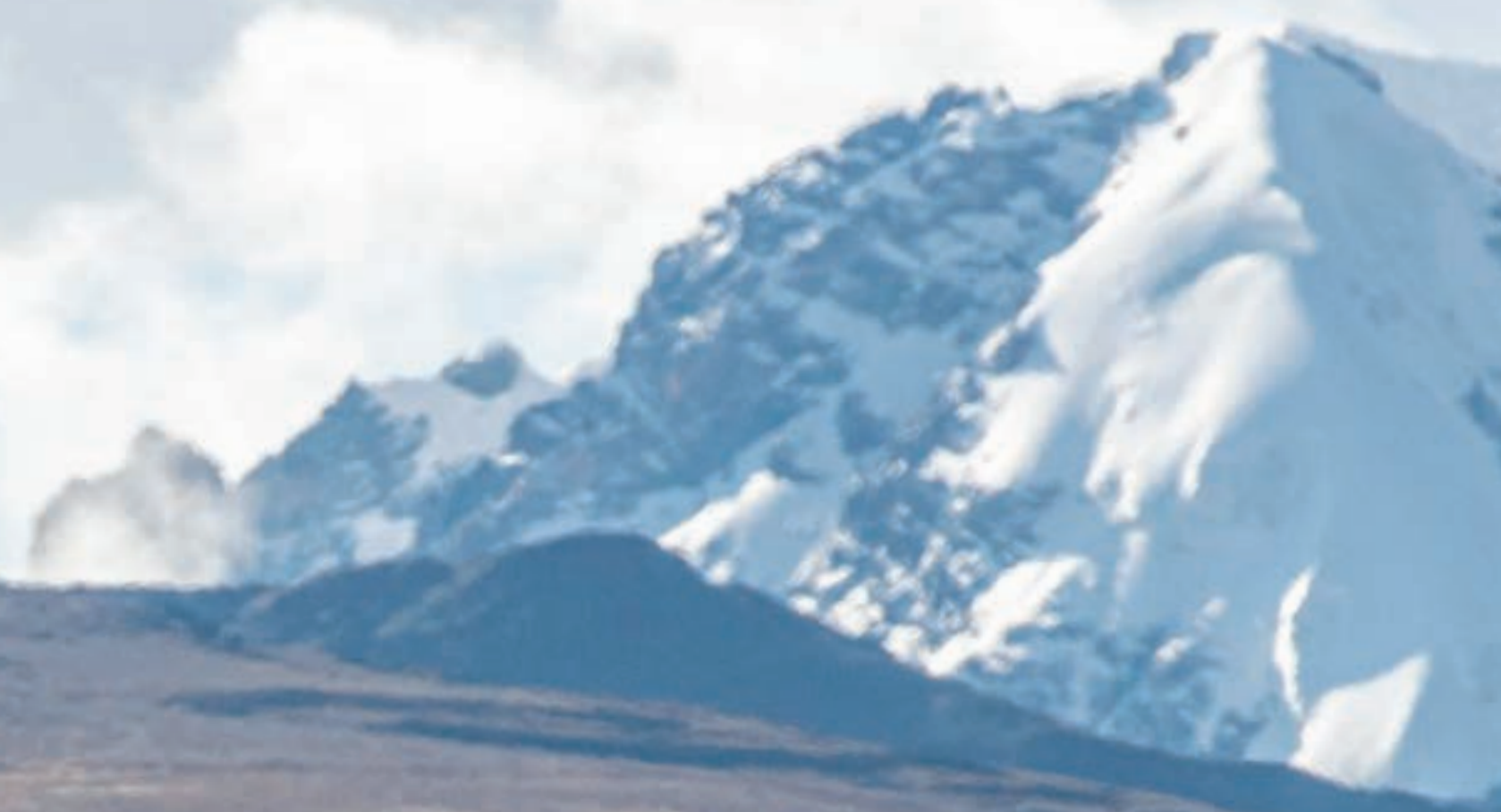

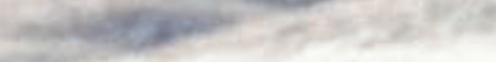

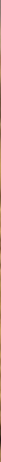

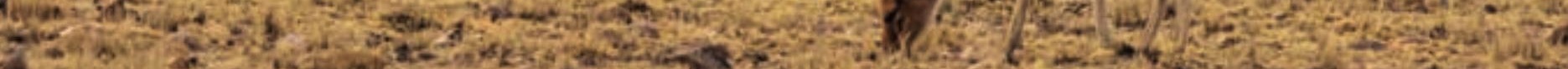

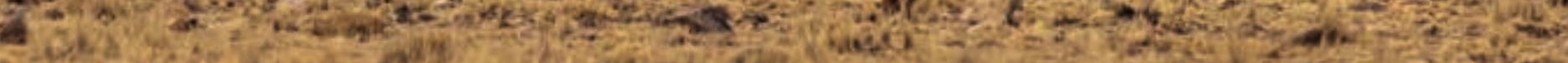

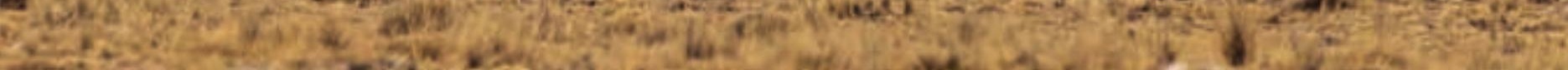

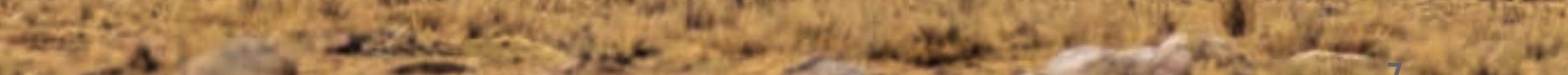

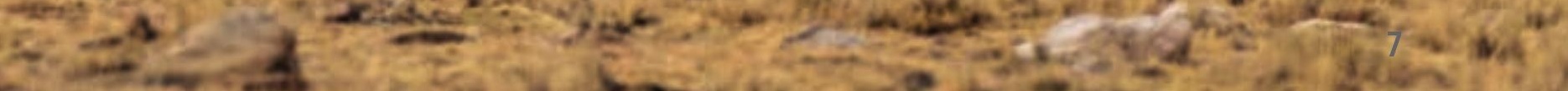


Sapajus apella-RobertWallace/WCS

r.

P.

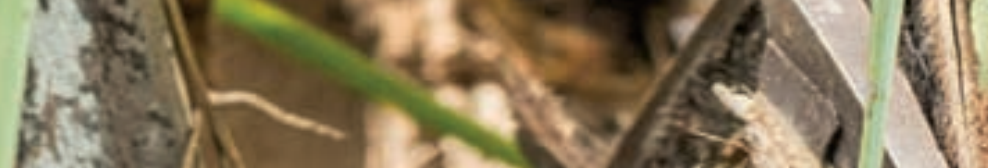

Q

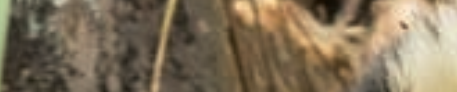

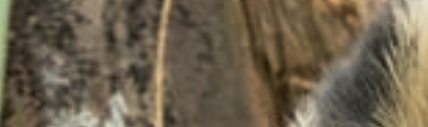

$(\cos x)$

800

3.t.

are

39.

3.7.

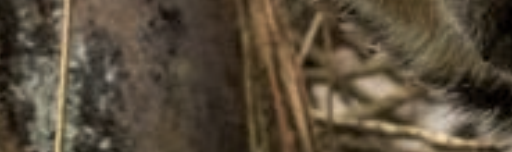

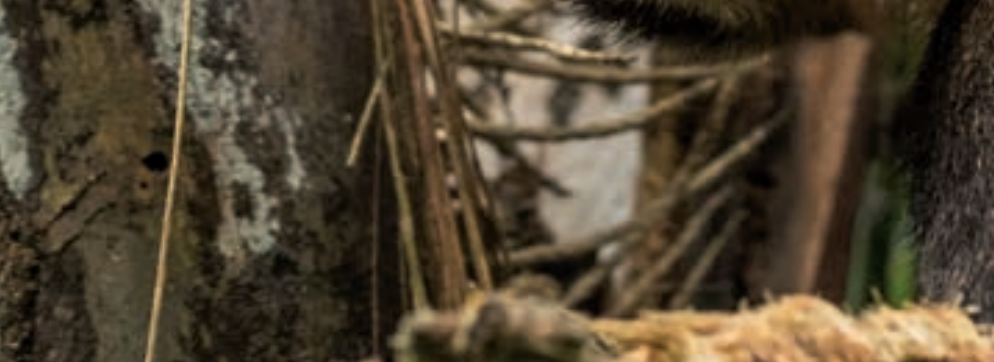

$\cos ^{2}(2,1)$

$\frac{2}{2}$

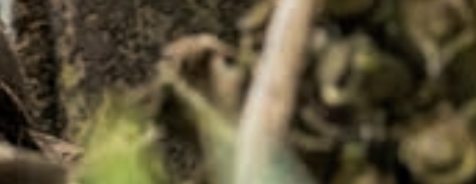

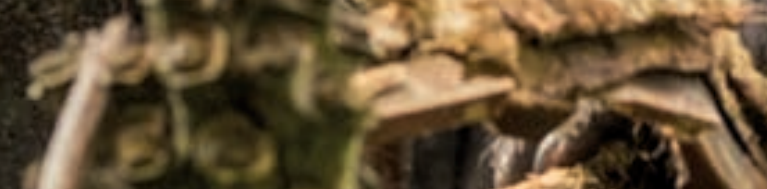

Q $p 2 a$

प 


\section{INTRODUCTION}

Biodiversity is a biological concept that describes the variability of all living things and can be measured and observed by the number of biological elements that coexist in certain dimensions of time and space (Cayuela \& Granzow-de la Cerda, 2012). These variations are recognized in genes, individuals, species, communities and ecosystems. Species diversity includes speciation processes, population interaction, and extinctions, while ecosystem diversity includes ecological processes and interaction among different species (Ibisch, 2003). Genetic diversity provides organisms with small distinctions that determine differential survival and reproduction, which allow the evolution of species through natural selection processes (Jiménez-Sierra, 2016).

Biological diversity is not homogeneously distributed on the planet, and the largest nations are not necessarily the most diverse. On a global scale, there are more species per unit area in the tropical regions than in those with temperate or cold climates (Jiménez-Sierra, 2016). Tropical forests cover only $10 \%$ of the earth's surface. However, their importance on a global scale is significant because in addition to hosting more than $70 \%$ of the total species of mammals, birds, reptiles, amphibians, plants and insects on the planet (Malhi, 2000; Groombridge, 2003; UNEP, 2010), they capture and process large amounts of carbon released into the atmosphere by human activity due to the consumption of fossil fuels (Wright, 2010). Through satellite images, it has been estimated that tropical forests cover about 11 million $\mathrm{km}^{2}$ (Achard, 2007). The largest area is in the Americas (55\%), followed by Asia (33.8\%) and Africa (11.2\%). Thus, the tropical region of the American continent, also known as the Neotropics, is of great interest for the study of biodiversity and its conservation (Cayuela \& Granzow-de la Cerda, 2012).

South America holds almost half of the world's tropical forests and is the most biologically diverse region in the world (UNEP, 2010). Of the 14 countries that make up this region, eight of them include portions of the Amazon region: Brazil, Peru, Ecuador, Colombia, Bolivia, Guyana, Suriname, French Guiana and Venezuela. According to the classification of South American bird species (BirdLife, 2018), the total number of species is 3,607, of which 2,502 are found in the Amazon. As for am phibians, the AmphibiaWeb portal records a total of 2,921 species for South America and 1,350 species for the Amazon. Finally, in the case of mammals, the International Union for Conservation of Nature (IUCN, 2019) reports that South America has 1,385 species, of which 874 are found in the Amazon. 
Currently, biodiversity faces threats that are also not evenly distributed over the surface of the planet. Large-scale destruction, degradation, and pollution of natural habitats, along with the introduction of exotic species and the effects of climate change, threaten biodiversity today. For these reasons, and considering that the Andes-Amazon is one of the regions with the greatest biodiversity and endemism, it is important to identify priority areas for conservation (Buytaert et al., 2011; Young et al., 2015).

The Wildlife Conservation Society (WCS) implements a successful landscape conservation program accross the world, based on wilderness sites relevant for their outstanding biodiversity and wildlife values. The WCS mission is to save wild life and natural landscapes around the world through science, conservation action, education, and inspiring people to value nature. To this end, WCS focuses its efforts on 15 regions of the world that include landscapes and seascapes, which are characterized by encompassing intact natural areas, representing the planet's biodiversity and being resilient to climate change or providing opportunities for species to adapt to environmental changes. One of these regions is formed by the Andes and the Amazon, harboring the largest tropical forest and the largest freshwater network in the world, providing a wide variety of extraordinary environmental services. WCS has prioritized five landscapes in the Andes-Amazon that integrate protected areas, indigenous territories and natural spaces.

Determining the biological diversity in each landscape and the groups of landscapes as a whole, and listing the threatened species and the endemic species they contain, will help to demonstrate the importance of actions for their conservation. From a biodiversity perspective, this spatially explicit information can also be used to identify priority areas for conservation. Finally, the results generated in the analysis herein will help disseminate to decision makers, funders and broader society, the conservation efforts that WCS carries out in these globally significant landscapes. 


\section{OBJETIVES}

\section{i. General Objective}

- To estimate the number of vertebrate species in five Andes-Amazon landscapes supported by WCS conservation programs.

\section{ii Specific Objectives}

- To compile theoretical lists of three groups of vertebrates (amphibians, birds and mammals) for each landscape where WCS works, using available spatial distribution data.

- Systematize information about the presence of three groups of vertebrates (amphibians, birds and mammals) in landscapes supported by WCS in the Andes-Amazon, and conduct a comparative analysis on reported species versus expected species according to the theoretical lists.

- Determinethe percentage of overlap between the five priority landscapes in theAndes-Amazon and published priority conservation units for five landscape species.

\section{METHODS}

The study area is delimited by the Amazon basin. This hydrogeographic area comprises approximately 6.3 million $\mathrm{km}^{2}$ (Milliman \& Farnsworth, 2011). WCS has prioritized its conservation efforts in the following five landscapes in the Amazon Basin (Figure 1):

- $\quad$ Pie de Monte/Putumayo (Colombia)

- Yasuní(Ecuador)

- $\quad$ Río Negro (Brazil)

- Marañón-Ucayalí(Peru)

- Madidi-Tambopata (Bolivia \& Peru)

To systematize information on the species in the five landscapes, three groups of vertebrates were initially selected: amphibians, birds and mammals, as there is a greater knowledge the spatial distribution of these groups. We compiled spatial data (in ESRI format) obtained from the IUCN (International Union for Consenvation of Nature), through the http://www.iucnredlist.org/technical-documents/ spatial-data portal and from Birdlife (2018). 


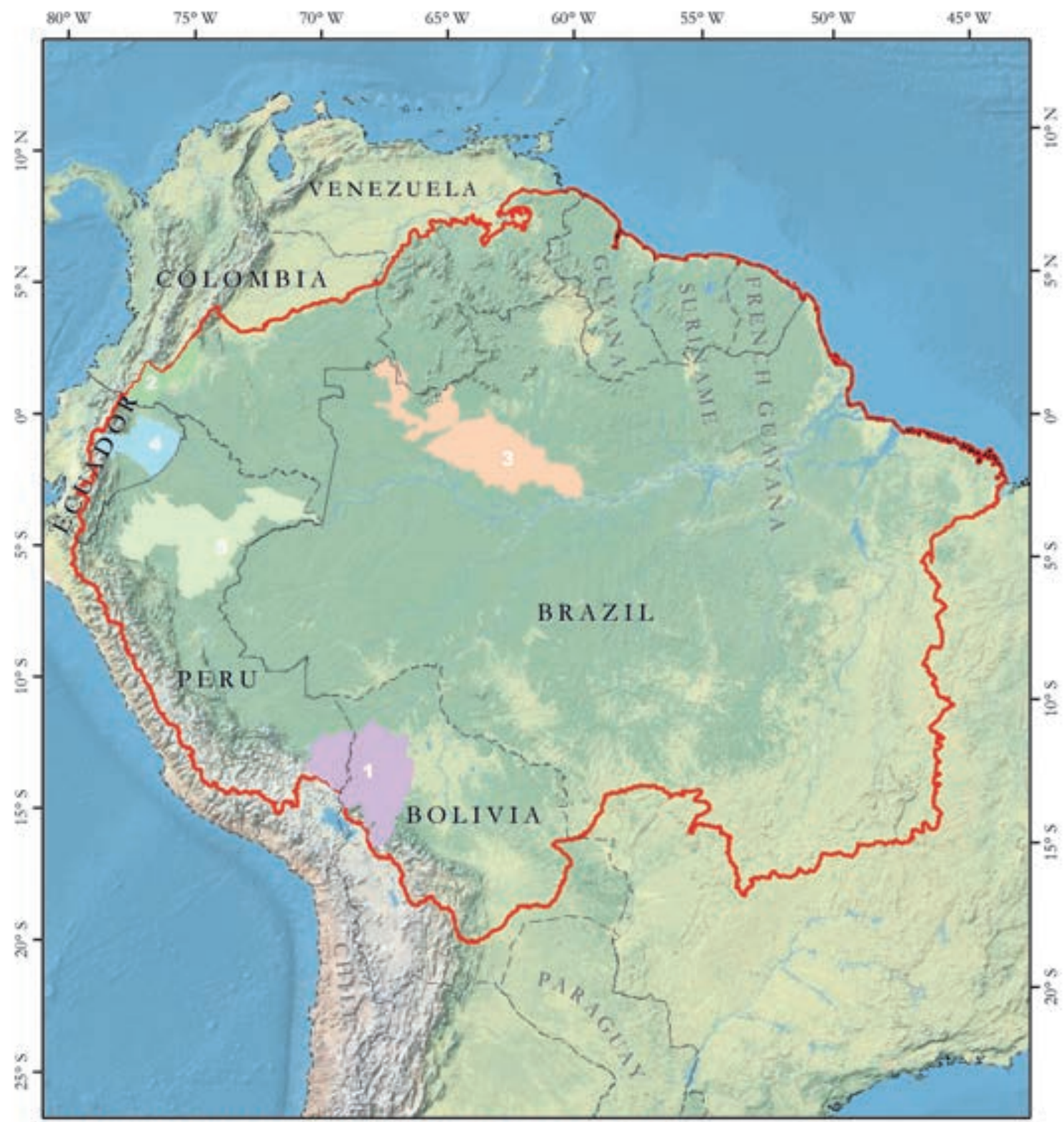

MAP OF PRIORITY CONSERVATION LANDSCAPES IN

THE ANDES-AMAZON LANDSCAPES SUPPORTED BY WCS IEGEND

CARTOGRAPHIC INFORMATION

International boundaries $\mathcal{B}$ Amazon basin

\section{WCS IANDSCAPES}

05. 1 - Madidi - Tambopata

25. Putumayo

06 3 - Rio Negro

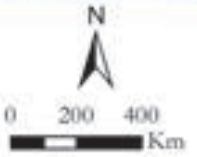

$1: 22,000,000$

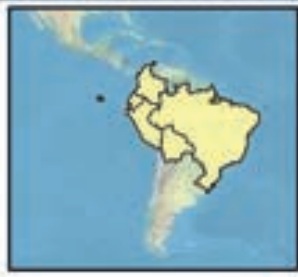

Figure 1: Limits of the Amazon basin and five landscapes supported by the Wild life Conservation Society (WCS) 
To generate a final list of expected species for each of the conservation landscapes supported by WCS in the AndesAmazon, an intersection was made between the spatial data for each species in the selected vertebrate groups and the conservation landscape limits.

Regarding the species reported and confirmed as present in each of the landscapes, species lists and information on the presence of vertebrates (amphibians, birds and mammals) were compiled from biodiversity surveys and/or studies conducted by WCS. In addition, a thorough review of different bibliographic sources related to biological inventories was carried out for each landscape, including protected area management plans, indigenous territory life plans, technical documents and other sources that refer to each landscape. The information on reported and confirmed species was assembled for the Madidi-Tambopata, Marañón-Ucayalí, Río Negro, and Yasuní landscapes, whereas for the Pie de Montel Putumayo landscape only a theoretical list of possible species present was obtained. Therefore, information on reported species for this landscape was not included in the analysis.

Based on this information, a list of confirmed amphibians, birds and mammals was elaborated for each landscape. Finally, these confirmed species lists were compared with the lists of expected species, thus obtaining a total number of registered species and expected species in each of the five landscapes. 
The taxonomic nomenclature varied among different sources,

it was therefore important to standardize information for each group:

- Amphibians: The list of registered and expected species was compared with the taxonomic data of the IUCN (2019), AmphibiaWeb (2018) and the American Natural History Museum (2018), using the latter two as the main taxonomic reference sources.

- Birds: The IUCN/BirdLife species list was compared with the Birdlife list (2018), and the latter selected as the main taxonomic reference source.
- Mammals: The species lists of Salazar-Bravo (2002), Wilson \& Reeder (2005), Gardner (2008), Wallace and colleagues (2010), IUCN (2019) and Patton and colleagues (2015) were used as the main taxonomic sources.

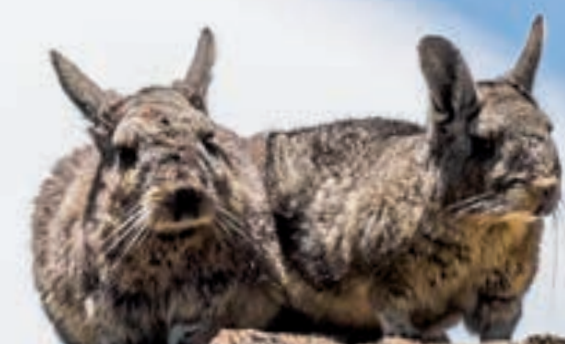




\section{RESULTS}

The analysis of the diversity of amphibians, birds and mammals that characterizes the Andes-Amazon region is presented on two levels: by country and by landscape. Comparisons of reported species with expected species at the level of the Amazon, South America and the world are also shown. It should be noted that the information on expected species comes from the spatial database of the International Union for Conservation of Nature (IUCN, 2018). The registered species data was collected from different sources in each landscape and provided by the WCS programs in the countries that collectively make up the WCS conservation program in the Andes-Amazon.
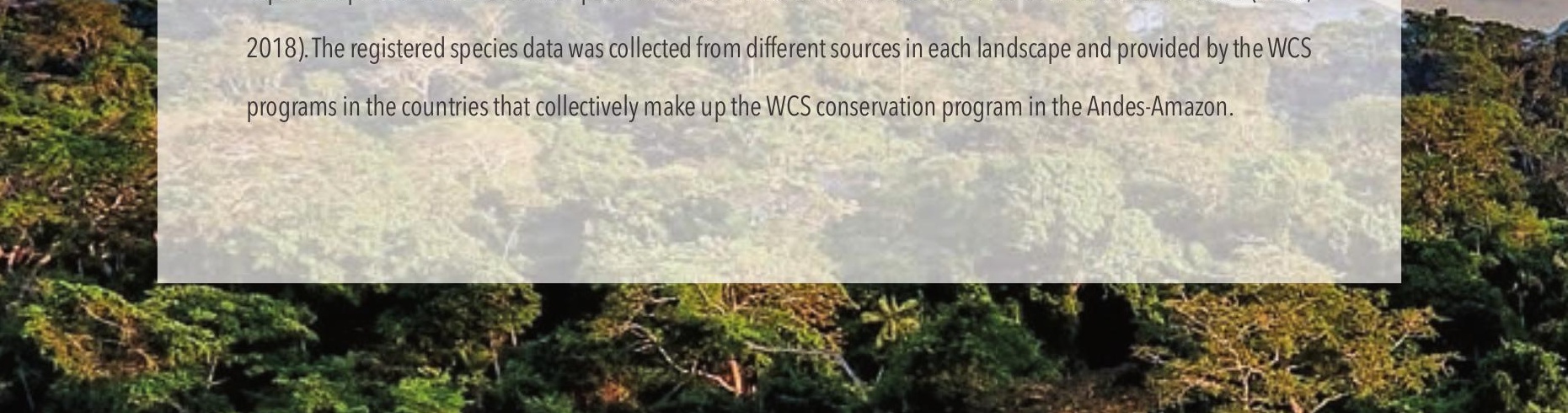

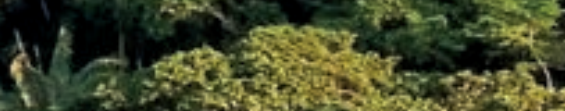

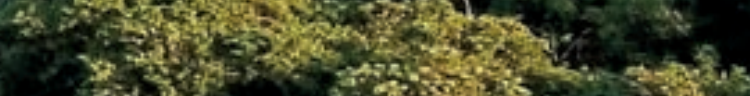

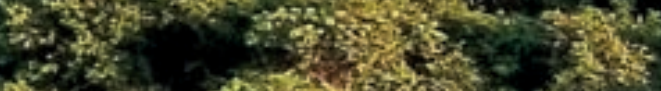
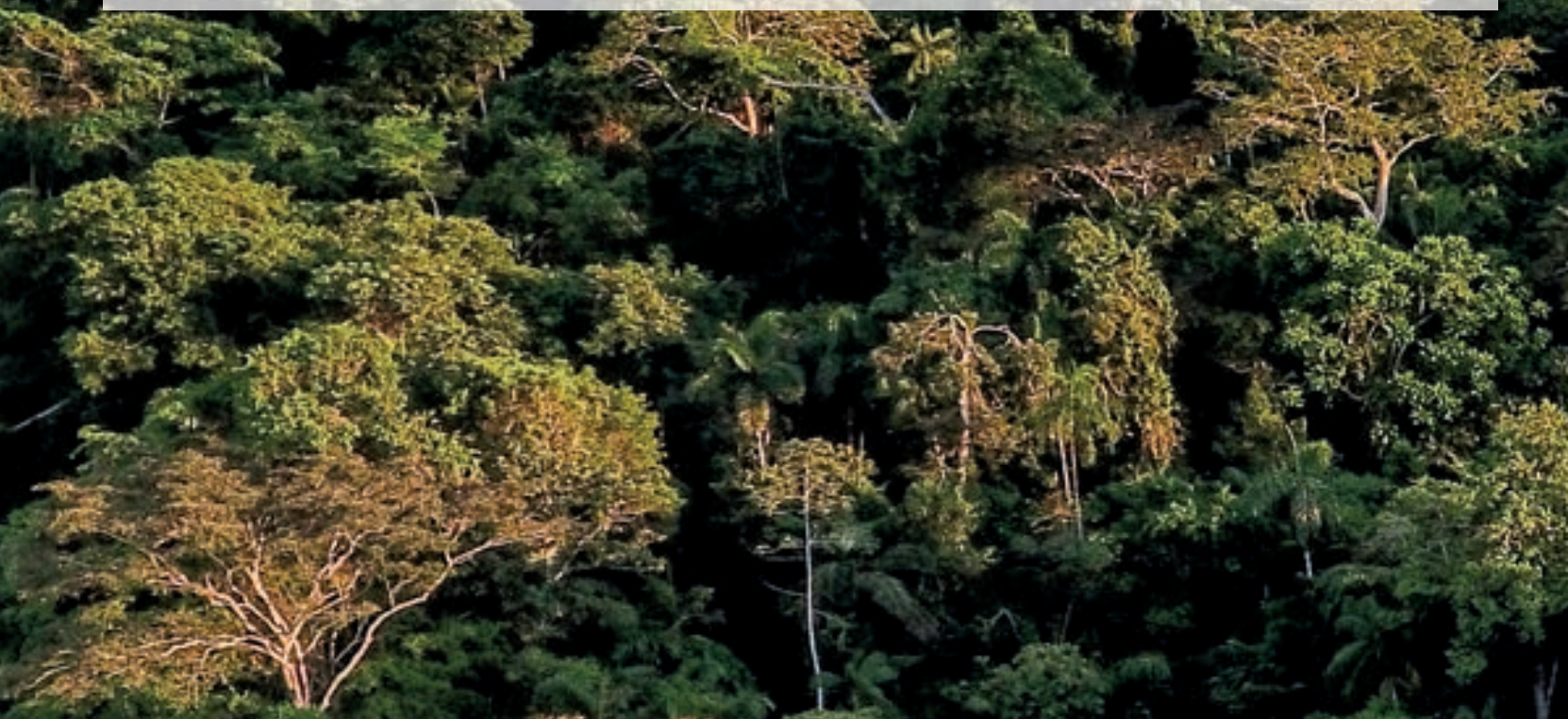

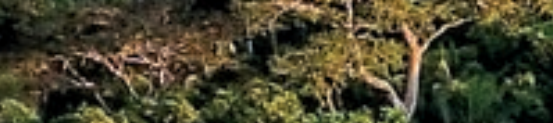
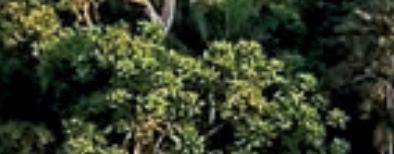

sicision anc

(2)
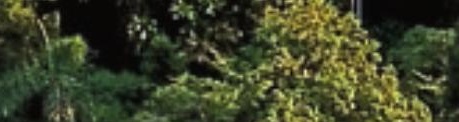

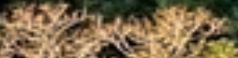
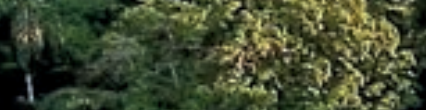
3.9.
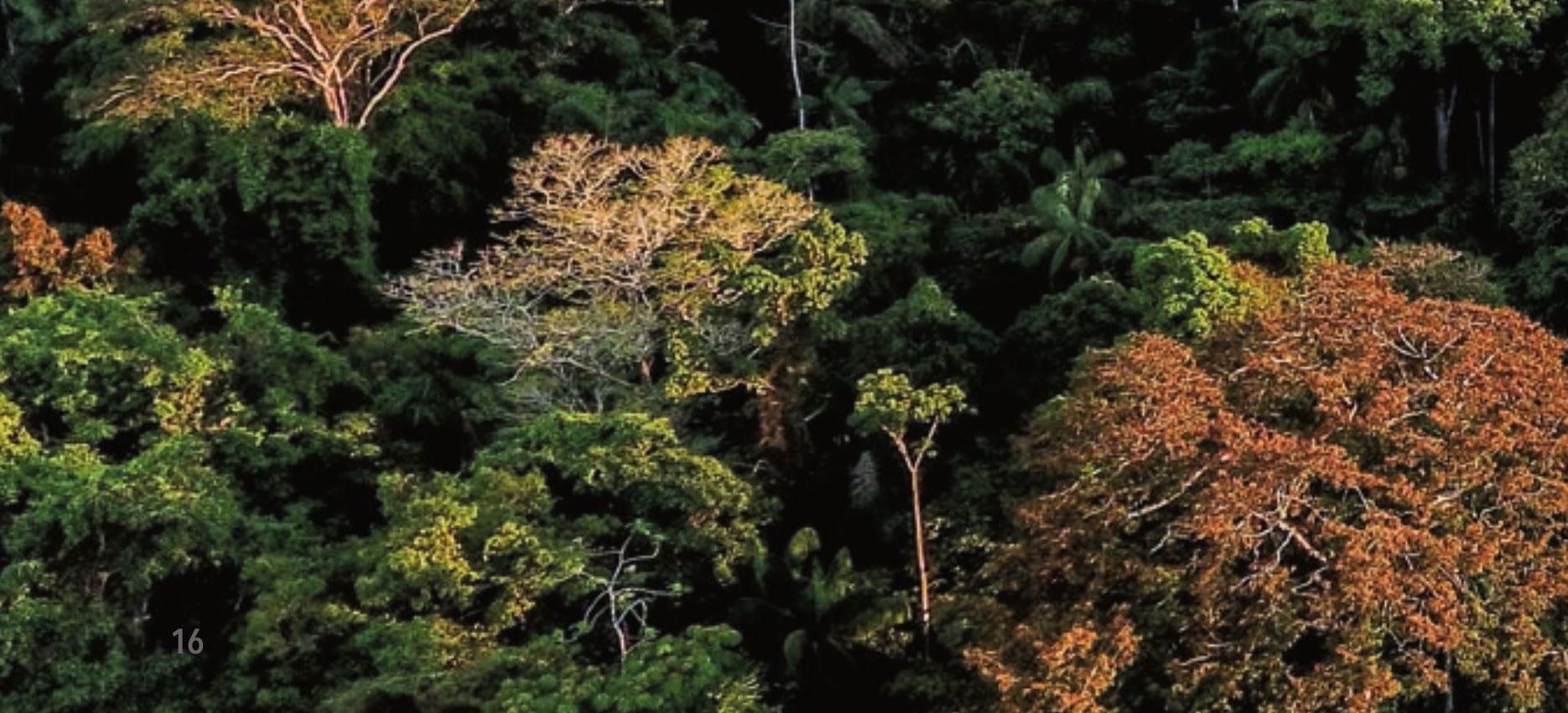


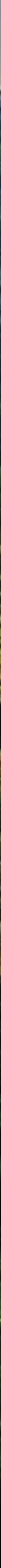




\section{a. Amphibians}

Bolivia. According to data obtained from the AmphibiaWeb portal (2019) and the IUCN (2019), the total number of amphibians reported in the country is 284 species. In the Madidi landscape, 111 species have been recorded (Emmons, 1990; SERNAP, 2007; SERNAP \& CRTM, 2009; Domic et al., 2012), which corresponds to $39.08 \%$ of Bolivia's amphibians. This number will increase with the new records generated in ongoing research such as the Identidad Madidi scientific expedition. Comparing the species recorded in the Madidi landscape with the expected species in the Amazon $(1,350)$ (IUCN, 2018), it has been estimated that $8.22 \%$ of Amazonian amphibians are found in the landscape. In addition, it is home to $3.8 \%$ of the amphibian species of South America and $1.38 \%$ of those in the world (AmphibiaWeb, 2019).

Peru. AmphibiaWeb data (2019) indicates that Peru has a total of 662 species. According to the data reviewed (Emmons \& Rodriguez, 1994; Rodriguez \& Knell, 2003), the number of amphibians estimated for the Tambopata and Yavari Samiria landscapes amounts to 110 species, which corresponds to $17,68 \%$ of the country's amphibians. This estimated number is equivalent to $8.14 \%$ of Amazonian amphibian species, $3.7 \%$ of those in South America and $1.37 \%$ of those in the world.

Ecuador. The total number of amphibians expected in Ecuador is 576 species (AmphibiaWeb, 2019). According to the data reported in different sources of landscape biodiversity surveys (Ortiz \& Morales, 2000; Ortega, 2010), 139 species have been identified in the Yasuní landscape. This number is equivalent to $24.13 \%$ of Ecuador's amphibian species, $10.3 \%$ of those in the Amazon, $4.76 \%$ of those in South America, and $1.27 \%$ of those in the world. 
Colombia. The total number of amphibians estimated for Colombia is 792 species (AmphibiaWeb, 2019). However, little bibliographic information was found to estimate the number of amphibians present in the Pie de Monte/Putumayo landscape (Betancourth-Cundar, 2010). According to information obtained from spatial data on amphibian distribution from the IUCN (2019) and the Global Biodiversity Information Facility (2016), we estimate that approximately 196 species occur in this landscape. Although this information gives us an idea of expected species that may be present, it is important to clarify that it represents only the potential species in the area, and not the reported species.

Brazil. AmphibiaWeb (2019) reports that the number of species for Brazil totals 1,103 amphibians. From different sources and data provided by WCS Brazil , 102 amphibians were identified in the Rio Negro landscape, representing $9.24 \%$ of the amphibians in Brazil and $7.56 \%$ of those in the Amazon. In addition to the Amazon, Brazil has many different biomes, so the total number of species in the country is greater than the number of species in the Amazon. The reported species represent 3.49\% of the amphibian species in South America and $1.27 \%$ of those in the world.

Finally, Table 1 details the number of amphibian species reported in each of the landscapes and the comparisons with the different spatial levels (country, Amazon, South America and world).

Table 1: Number of amphibian species reported in the landscape of each country and the total number of amphibian species estimated for each country, the Amazon, South America and the world. For Colombia, no data was available for reported species in the Pie de Monte/Putumayo landscape.

\begin{tabular}{|c|c|c|c|c|c|}
\hline $\begin{array}{l}\text { COUNTRIES } \\
\text { (Landscapes) }\end{array}$ & $\begin{array}{l}\text { Bolivia } \\
\text { (Madidi) }\end{array}$ & $\begin{array}{c}\text { Peru } \\
\text { (Tambopata/Marañón-Ucayali) }\end{array}$ & $\begin{array}{l}\text { Ecuador } \\
\text { (Yasuni) }\end{array}$ & $\begin{array}{l}\text { Colombia } \\
\text { (Pie de Monte/Putumayo) }\end{array}$ & $\begin{array}{c}\text { Brazil } \\
\text { (Río Negro) }\end{array}$ \\
\hline Number of reported amphibian species & 111 & 110 & 139 & - & 102 \\
\hline Total number of amphibian species in country & 284 & 622 & 576 & 792 & 1.104 \\
\hline Percentage of amphibians in country & $39.08 \%$ & $17.68 \%$ & $24.13 \%$ & - & $9.24 \%$ \\
\hline $\begin{array}{l}\text { Percentage of amphibian species in the Amazon } \\
\text { (1,350 species) }\end{array}$ & $8.22 \%$ & $8.14 \%$ & $10.3 \%$ & - & $7.56 \%$ \\
\hline $\begin{array}{l}\text { Percentage of amphibian species in South } \\
\text { America }(2,921 \text { species })\end{array}$ & $3.8 \%$ & $3.7 \%$ & $4.76 \%$ & - & $3.49 \%$ \\
\hline $\begin{array}{l}\text { Percentage of amphibian species in the world } \\
(8,018 \text { species) }\end{array}$ & $1.38 \%$ & $1.37 \%$ & $1.73 \%$ & - & $1.27 \%$ \\
\hline
\end{tabular}




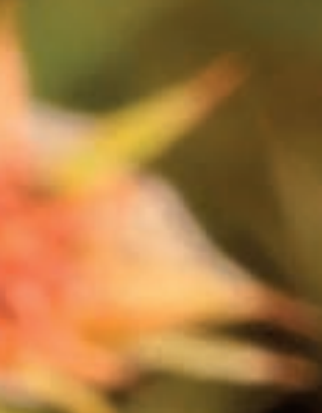


The following analysis contrasts the number of amphibians reported with the number of amphibians expected in each landscape. The expected amphibian numbers are the result of the intersection of the IUCN (2019) spatial data on amphibian distribution and the boundaries of each WCS Andes-Amazon conservation landscape. The data reported for each landscape is the result of systematization of bibliographic sources, as well as data sent by each of the WCS programs.

Madidi-Tambopata Landscape. This transboundary landscape is shared by Bolivia and Peru. According to information from the IUCN (2019), it is estimated that there are 203 species of amphibians in the landscape. Recorded species from research and different bibliographic sources (Emmons, 1990; Emmons \& Rodriguez, 1994; Domic et al., 2012) amount to 118 amphibian species. This indicates that there is corroborated knowledge about the presence of $58.13 \%$ of expected amphibian species for this landscape. The data on reported species show that the landscape is home to $8.73 \%$ of Amazonian amphibians, $4.04 \%$ of South American amphibian, and $1.47 \%$ of amphibians worldwide.

Marañón-Ucayalí Landscape. A total of 207 species of amphibians were estimated for this landscape. According to bibliographic references (Rodriguez \& Knell, 2003) and data from WCS Peru, 60 amphibian species have been identified in this landscape, representing $29 \%$ of amphibian species expected in this landscape, constituting $4.44 \%$ of the amphibians of the Amazon, $2.05 \%$ of those of South America, and $0.75 \%$ of the world.

Yasuni Landscape. The number of amphibian species estimated for this landscape is 231. Published records (Ortiz \& Morales, 2000; Ortega, 2010) and data from WCS Ecuador report 139 species, representing 60.17\% of the amphibian species expected for this landscape. The registered species represent $10.3 \%$ of the amphibians of the Amazon, $4.76 \%$ of those of South America, and $1.73 \%$ of those of the world.

Pie de Monte/Putumayo Landscape. The number of amphibian species expected in this landscape is 198 species. Due to the limited literature available for the three vertebrate groups in this landscape (Betancourth-Cundar, 2010), there is not enough information to define a given number of confirmed amphibians in this landscape. If expected species data were considered, they would represent $13.11 \%$ of the amphibian species present in the Amazon, 6.06\% at the level of South America, and $2.21 \%$ at the global level.

Rio Negro Landscape. According to bibliography and data from WCS Brazil, the number of species registered in this landscape is 102 amphibians, while expected species reach 144 species, with registered species representing $70.83 \%$ of expected species. The species registered so far correspond to $7.56 \%$ of the amphibians in the Amazon, 3.49\% of those in South America, and $1.27 \%$ of those in the world. 
Table 2 details the percentage of representativeness of each landscape at the level of the Amazon, South America and the world. Figure 2 contrasts reported species in each of landscape with those expected to occur.

Table 2: Number of reported and expected amphibian species for each of the Andes-Amazon landscapes supported by WCS and comparison of reported amphibian species with estimated amphibian species totals for the Amazon, South America and the world. Only expected species are included for the Pie de Monte/Putumayo landscape in Colombia.

\begin{tabular}{|c|c|c|c|c|c|c|c|c|c|c|c|c|}
\hline \multirow{2}{*}{$\begin{array}{l}\text { LANDSCAPES } \\
\text { Andes-Amazon }\end{array}$} & \multicolumn{2}{|c|}{ Madidi-Tambopata } & \multicolumn{2}{|c|}{ Marañón Ucayali } & \multicolumn{2}{|c|}{ Yasuní } & \multicolumn{2}{|c|}{ Pie de Monte/ Putumayo } & \multicolumn{2}{|c|}{ Río Negro } & \multicolumn{2}{|c|}{ Landscapes Total } \\
\hline & Reported & Expected & Reported & Expected & Reported & Expected & Reported & Expected & Reported & Expected & Reported & Expected \\
\hline $\begin{array}{l}\text { Number of reported and expected } \\
\text { amphibian species in each landscape }\end{array}$ & 118 & 203 & 60 & 207 & 139 & 231 & - & 177 & 102 & 144 & 264 & 508 \\
\hline $\begin{array}{l}\text { Percentage of expected amphibians } \\
\text { reported in the landscape }\end{array}$ & \multicolumn{2}{|c|}{$58.13 \%$} & \multicolumn{2}{|c|}{$29 \%$} & \multicolumn{2}{|c|}{$60.17 \%$} & \multicolumn{2}{|c|}{ - } & \multicolumn{2}{|c|}{$70.83 \%$} & \multicolumn{2}{|c|}{$52 \%$} \\
\hline $\begin{array}{l}\text { Percentage of amphibian species in } \\
\text { the Amazon ( } 1,350 \text { species) }\end{array}$ & $8.74 \%$ & $15.04 \%$ & $4.44 \%$ & $15.33 \%$ & $10.3 \%$ & $17.11 \%$ & - & $13.11 \%$ & $7.56 \%$ & $10.67 \%$ & $19.56 \%$ & $37.63 \%$ \\
\hline $\begin{array}{l}\text { Percentage of amphibian species in } \\
\text { South America (2,921 species) }\end{array}$ & $4.04 \%$ & $6.95 \%$ & $2.05 \%$ & $7.09 \%$ & $4.76 \%$ & $7.91 \%$ & - & $6.06 \%$ & $3.49 \%$ & $4.93 \%$ & $9.04 \%$ & $17.39 \%$ \\
\hline $\begin{array}{l}\text { Percentage of amphibian species in } \\
\text { the world ( } 8,018 \text { species) }\end{array}$ & $1.47 \%$ & $2.53 \%$ & $0.75 \%$ & $2.58 \%$ & $1.73 \%$ & $2.88 \%$ & - & $2.21 \%$ & $1.27 \%$ & $1.8 \%$ & $3.29 \%$ & $6.34 \%$ \\
\hline
\end{tabular}
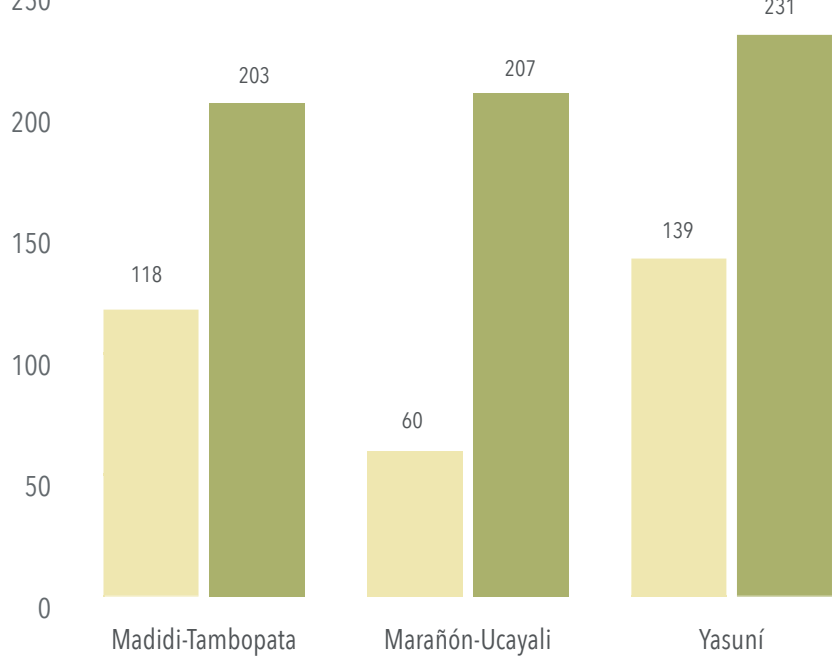

Yasuní

Pie de Monte

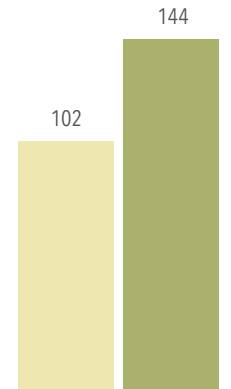

Río Negro

\section{Reported Expected}

Figure 2: Number of reported and expected amphibian species for each of the Andes-Amazon landscapes supported by WCS. Only expected species are included for the Pie de Monte/Putumayo landscape in Colombia. 


\section{b. Birds}

Bolivia. According to data obtained from Bird Life (2018), the total number of bird species for this country is 1,438 . In the Madidi landscape, 1,055 bird species have been registered (Parker, 1990; Herzog et al., 2016; Avibase, 2016; eBird, 2016), corresponding to $73.37 \%$ of Bolivia's bird species. The species registered in the Madidi landscape amount to $42.17 \%$ of expected species in the Amazon $(2,502), 29.25 \%$ of birds in South America, and $9.48 \%$ of birds worldwide.

Peru. BirdLife (2018) data show that Peru is home to 1,888 bird species. According to the bibliographic sources reviewed (Lane \& Flores, 2003), the number of birds registered in the Tambopata and Marañón-Ucayalílandscapes is 828, corresponding to 43.86\% of the species present in the country. Likewise, this number is equivalent to $33.09 \%$ of the bird species of the Amazon, $22.96 \%$ of those of South America, and $7.44 \%$ of those of the world.

Ecuador. According to BirdLife data (2018), Ecuador has a total of 1,687 bird species. Bibliographic sources (Benitez \& Sanchez, 2000) and information obtained from WCS Ecuador, show that 751 bird species have been registered in the Yasuni landscape, which corresponds to $44.52 \%$ of the birds in the country. In turn, this number is equivalent to $30.02 \%$ of the bird species in the Amazon, $20.82 \%$ of those in South America, and $6.75 \%$ of those in the world. 
Colombia. The number of birds estimated for Colombia is 1,905 species (BirdLife, 2018). It was not possible to collect information on the species registered in the Pie de Monte/Putumayo landscape. Using expected species data generated using spatial data from IUCN and BirdLife (2018), indicates that this landscape could contain 1,047 bird species, equivalent to $54.96 \%$ of the birds in Colombia, $41.85 \%$ of those in the Amazon, $29.03 \%$ of those in South America, and $9.4 \%$ of those in the world.

Brazil. The number of birds reported by BirdLife (2018) for Brazil amounts to 1,813 species. In the Rio Negro landscape, according to data from WCS Brazil, 660 bird species are registered. This number represents $36.4 \%$ of the birds present in Brazil, $26.38 \%$ of the birds in the Amazon, $18.3 \%$ of those in South America, and $5.93 \%$ of those in the world.

Finally, Table 3 details the number of bird species reported in each landscape compared with the different spatial levels (country, Amazon, South America and world).

Table 3: Number of birds species reported in the landscape of each country and the total number of birds species estimated for each country, South America and the world. For Colombia, no data was available for reported species in the Pie de Monte/Putumayo landscape.

\begin{tabular}{|l|c|c|c|c|}
\hline \multicolumn{1}{|c|}{$\begin{array}{c}\text { COUNTRIES } \\
\text { (Landscapes) }\end{array}$} & $\begin{array}{c}\text { Bolivia } \\
\text { (Madidi) }\end{array}$ & $\begin{array}{c}\text { Peru } \\
\text { (Tambopata/Marañón-Ucayali) }\end{array}$ & $\begin{array}{c}\text { Ecuador } \\
\text { (Yasuni) }\end{array}$ & $\begin{array}{c}\text { Colombia } \\
\text { Brazil } \\
\text { (Rí Negro) }\end{array}$ \\
\hline (Pie de Monte/Putumayo)
\end{tabular}




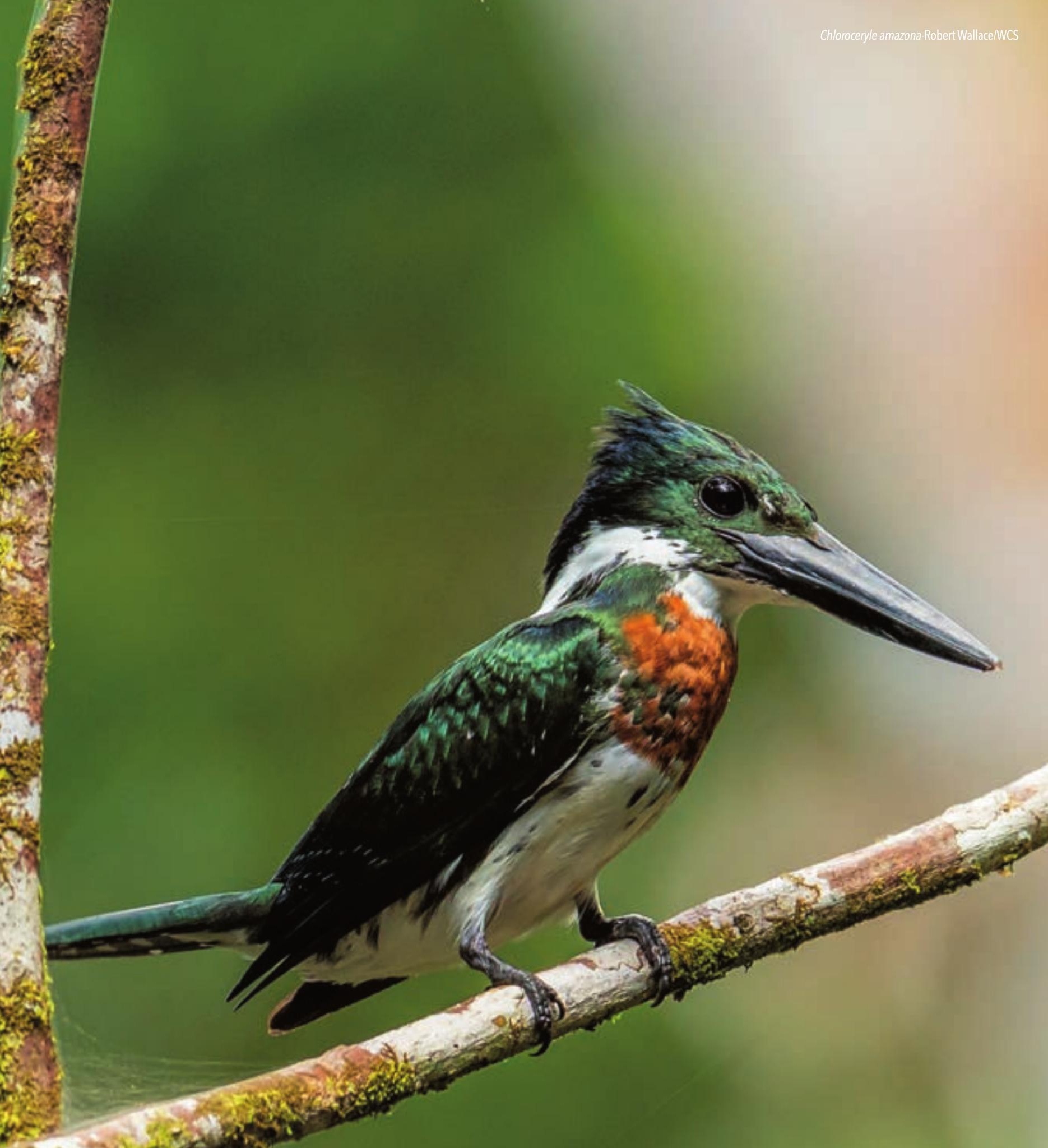

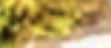

1)

topios

sent

30

ey

25

2010 
The following analysis contrasts the number of birds reported with the number of birds expected in each landscape. The expected bird numbers are the result of the intersection of the BirdLife (2018) spatial data on bird distribution and the boundaries of each WCS AndesAmazon conservation landscape. The data reported for each landscape is the result of systematization of bibliographic sources, as well as data sent by each of the WCS programs.

Madidi-Tambopata Landscape. According to Birdlife (2018) spatial information, we estimate that 1,243 bird species are present in this landscape. The species reported in different bibliographic sources for this landscape (Parker, 1990; Parker et al., 1994; Stotz et al., 2002) amount to 1,183 birds. This indicates that $95.17 \%$ of the bird species expected in the landscape have been confirmed to date. These data also show that this landscape is home to $47.28 \%$ of birds in the Amazon, $32.8 \%$ of those in South America, and $10.63 \%$ of those in the world.

Marañón-Ucayalí Landscape. We estimate a total of 963 bird species for this landscape. Bibliographical references (Lane \& Flores, 2003) report 397 bird species in this landscape, representing $41 \%$ of expected species. This number of species represents $15.87 \%$ of birds in the Amazon, $11 \%$ in South America, and $3.57 \%$ in the world.

Yasuni Landscape. For this landscape we estimate a total of 1,086 bird species. Bibliographic sources (Benitez \& Sanchez, 2000; eBird, 2016), and data provided by WCS Ecuador, revealed that 751 species are reported in the landscape, which corresponds to 69.15\% of expected species. The registered species represent $30 \%$ of Amazonian bird species, as well as $20.82 \%$ of birds in South America, and $6.75 \%$ of bird species in the world.

Pie de Monte/Putumayo Landscape. For this landscape, only IUCN spatial distribution data (2019) is available, which estimates 1,092 expected bird species in the landscape. There is no information available on registered species.

Rio Negro Landscape. The total number of expected birds is 849 species (BirdLife, 2018) and WCS Brazil systematized a total of 660 reported species in the landscape, which represents $77.74 \%$ of expected species. Likewise, the registered species represent $26.38 \%$ of Amazonian species, $18.3 \%$ of those in South America, and $5.93 \%$ of species in the world.

Table 4 details the percentage of representativeness of each landscape at the Amazon, South America and global levels. Figure 3 contrasts the expected species versus the species reported in each landscape. 
Table 4: Number of reported and expected bird species for each of the Andes-Amazon landscapes supported by WCS and comparison of reported amphibian species with estimated bird species totals for the Amazon, South America and the world. Only expected species are included for the Pie de Monte/Putumayo landscape in Colombia.

\begin{tabular}{|c|c|c|c|c|c|c|c|c|c|c|c|c|}
\hline \multirow{2}{*}{$\begin{array}{l}\text { LANDSCAPES } \\
\text { Andes-Amazon }\end{array}$} & \multicolumn{2}{|c|}{ Madidi-Tambopata } & \multicolumn{2}{|c|}{ Marañón Ucayali } & \multicolumn{2}{|c|}{ Yasuní } & \multicolumn{2}{|c|}{ Pie de Monte/Putumayo } & \multicolumn{2}{|c|}{ Río Negro } & \multicolumn{2}{|c|}{ Landscapes Total } \\
\hline & Reported & Expected & Reported & Expected & Reported & Expected & Reported & Expected & Reported & Expected & Reported & Expected \\
\hline $\begin{array}{l}\text { Number of reported and ex- } \\
\text { pected bird species in each } \\
\text { landscape }\end{array}$ & 1,183 & 1,243 & 397 & 963 & 751 & 1,086 & - & 1,092 & 660 & 849 & 1,514 & 1,836 \\
\hline $\begin{array}{l}\text { Percentage of expected birds } \\
\text { reported in the landscape }\end{array}$ & \multicolumn{2}{|c|}{$95.17 \%$} & \multicolumn{2}{|c|}{$41 \%$} & \multicolumn{2}{|c|}{$69.15 \%$} & \multicolumn{2}{|c|}{ - } & \multicolumn{2}{|c|}{$77.74 \%$} & \multicolumn{2}{|c|}{$82 \%$} \\
\hline $\begin{array}{l}\text { Percentage of bird species in the } \\
\text { Amazon (2,502 species) }\end{array}$ & $47.28 \%$ & $49.68 \%$ & $15.87 \%$ & $38.49 \%$ & $30.02 \%$ & $43.41 \%$ & - & $43.65 \%$ & $26.38 \%$ & $33.93 \%$ & $60.51 \%$ & $73.38 \%$ \\
\hline $\begin{array}{l}\text { Percentage of bid species in } \\
\text { South America }(3,607 \text { species })\end{array}$ & $32.8 \%$ & $34.46 \%$ & $11.01 \%$ & $26.7 \%$ & $20.82 \%$ & $30.11 \%$ & - & $30.27 \%$ & $18.3 \%$ & $23.54 \%$ & $41.97 \%$ & $50.9 \%$ \\
\hline $\begin{array}{l}\text { Percentage of bird species in the } \\
\text { world }(11,126 \text { species })\end{array}$ & $10.63 \%$ & $11.17 \%$ & $3.57 \%$ & $8.66 \%$ & $6.75 \%$ & $9.76 \%$ & - & $9.81 \%$ & $5.93 \%$ & $7.63 \%$ & $13.61 \%$ & $16.5 \%$ \\
\hline
\end{tabular}

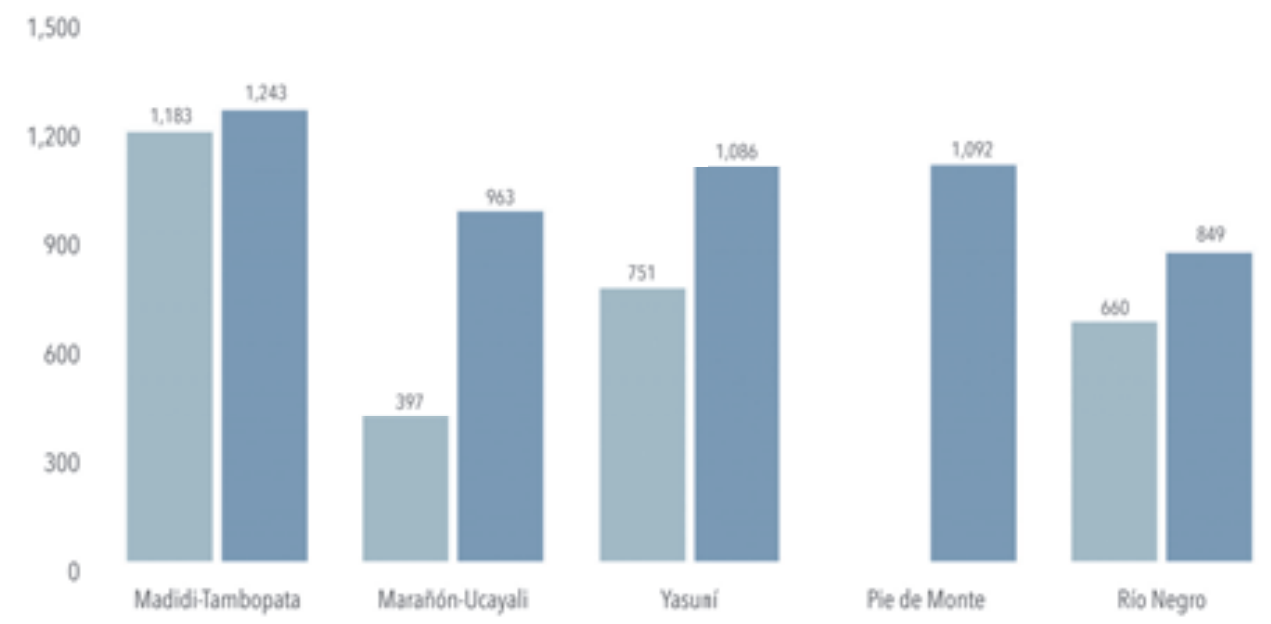

\section{Reported Expected}

Figure 3: Number of reported and expected bird species for each of the Andes-Amazon landscapes supported by WCS. Only expected species are included for the Pie de Monte/Putumayo landscape in Colombia. 


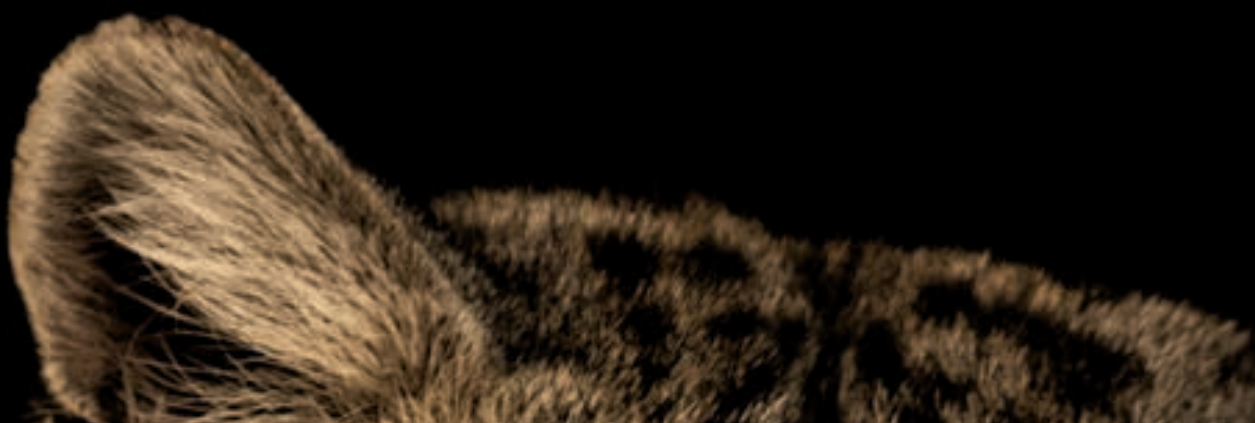

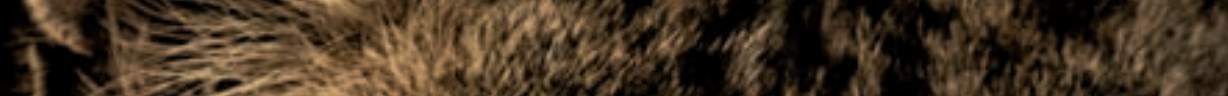

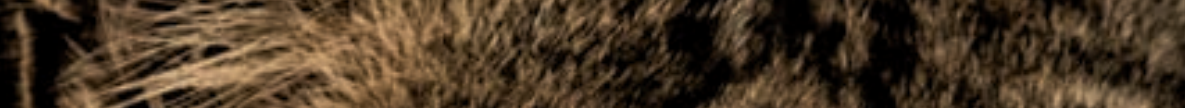

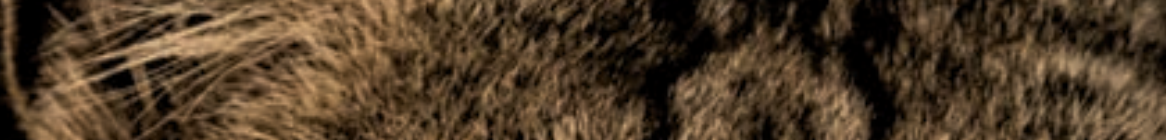

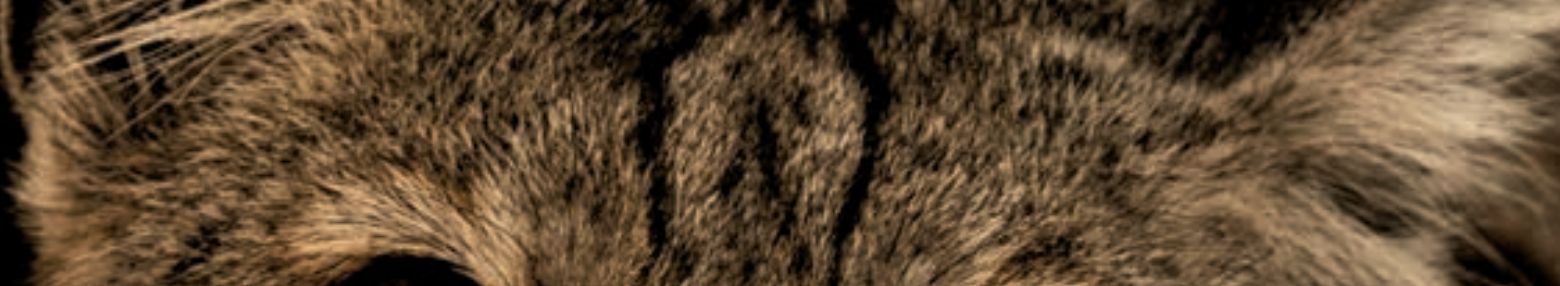
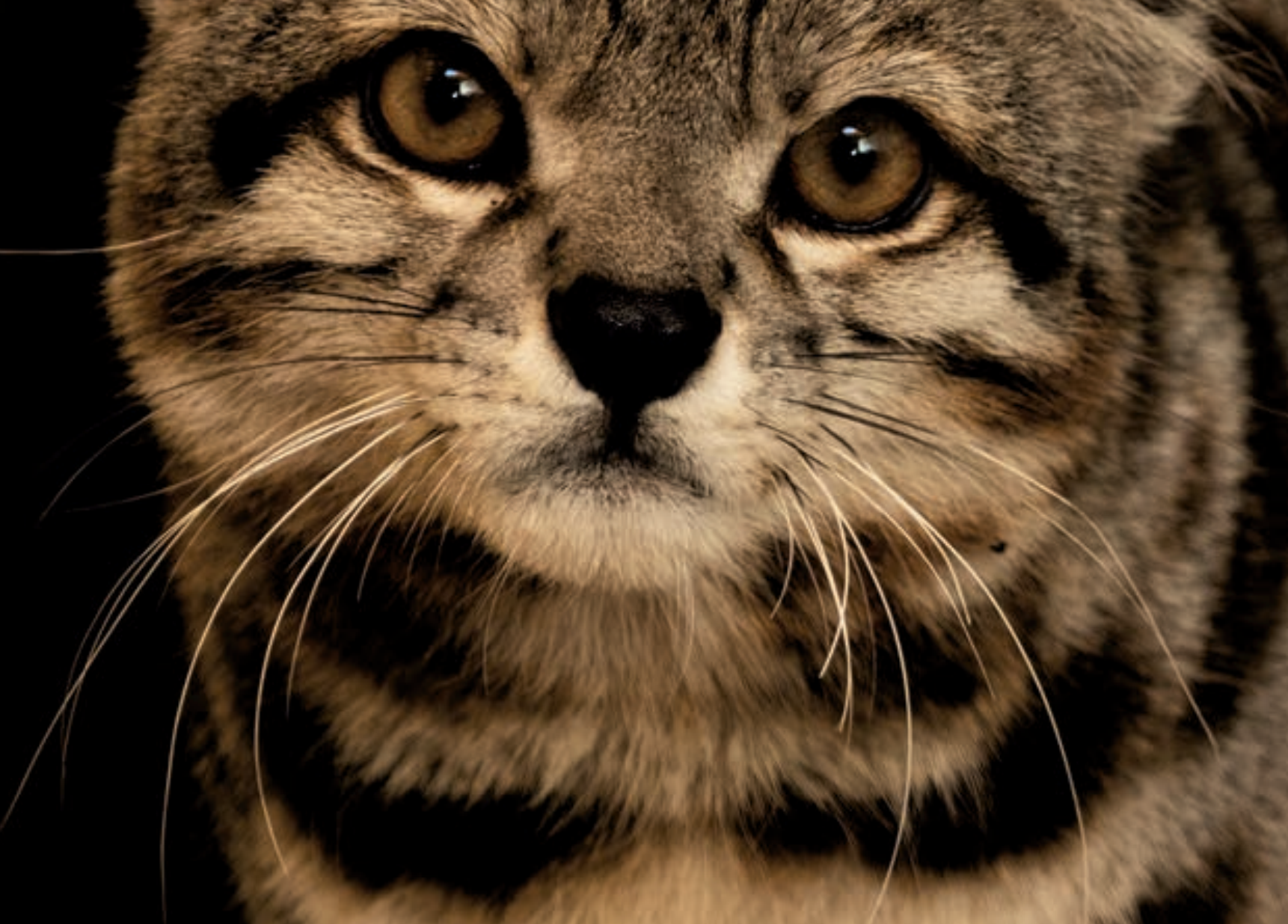

Es.
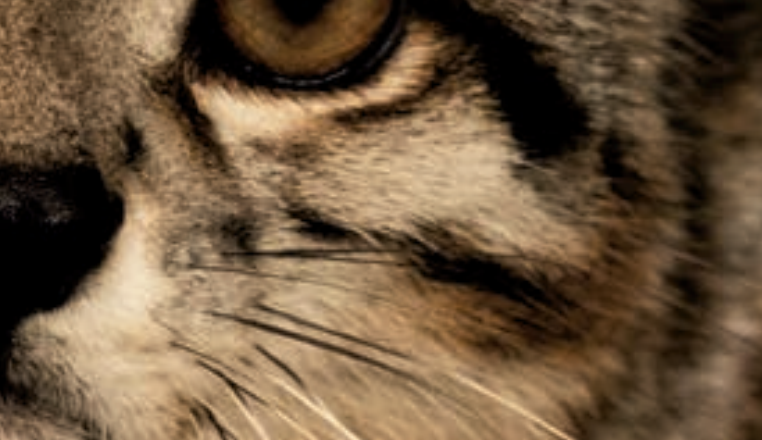


\section{c. Mammals}

Bolivia. IIUCN (2019) data estimates 432 mammal species for Bolivia. In the Madidi landscape, 253 species have been confirmed (Wallace et al., submitted), which is equivalent to $58.56 \%$ of the mammals in Bolivia. Comparisons of mammal species registered in the Madidi landscape and expected species in the Amazon (IUCN, 2019), 28.94\% are found in Madidi, which also hosts $18.26 \%$ of South American mammals, and $3.95 \%$ of global mammals (Wilson \& Reeder, 2016).

Peru. Using IUCN data (2019) we estimate 517 species of mammals for Peru. According to literature (Salovaara, 2003; Romo \& Emmons, 1991) and data at WCS Peru, the total number of species recorded between the Tambopata and Yavari Samiria landscapes is 256 species, corresponding to $49.52 \%$ of the species estimated for Peru. It also represents $29.29 \%$ of Amazonian mammals, $18.48 \%$ of those in South America, and $4 \%$ of those in the world (Wilson \& Reeder, 2016).

Ecuador. The total number of mammals estimated for Ecuador is 396 species (IUCN 2019). According to literature (Castro \& Román, 2000) and the data provided by WCS Ecuador, 168 species have been registered in the Yasuni landscape, which is equivalent to $42.42 \%$ of the estimated mammal species for the country. The registered species represent $19.22 \%$ of the mammals of the Amazon, $12.13 \%$ of those in South America, and $2.63 \%$ of those in the world. 
Colombia. IUCN (2019) data allows for an estimate of 498 mammal species for Colombia. Due to information gaps in the Pie de monte/ Putumayo landscape, we did not generate lists of reported species. Using IUCN (2019) data we estimate 278 species for this landscape, which would represent $55.82 \%$ of the mammals in the country, $31.81 \%$ of those in the Amazon, $20.07 \%$ of those in South America, and $4.34 \%$ of those in the world.

Brazil. IUCN (2019) data estimates 690 mammal species for Brazil. In the Rio Negro landscape, according to WCS Brazil, 172 species have been registered, representing $24.93 \%$ of the mammals in the country, $19.68 \%$ of those in Amazon, $12.42 \%$ of those in South America, and $2.69 \%$ of those in the world.

Finally, Table 5 details the number of mammal species reported in each landscape compared with the different spatial levels (country, Amazon, South America and world).

Table 5: Number of mammal species reported in the landscape of each country and the total number of mammal species estimated for each country, the Amazon, South America and the world. For Colombia, no data was available for reported species in the Pie de Monte/Putumayo landscape.

\begin{tabular}{|l|c|c|c|}
\hline \multicolumn{1}{|c|}{$\begin{array}{c}\text { COUNTRIES } \\
\text { (Landscapes) }\end{array}$} & $\begin{array}{c}\text { Bolivia } \\
\text { (Madidi) }\end{array}$ & $\begin{array}{c}\text { Peru } \\
\text { (Tambopata/Marańn-Ucayali) }\end{array}$ & $\begin{array}{c}\text { Ecuador } \\
\text { (Yasuni) }\end{array}$ \\
\hline Number of reported mammal species & 253 & $\mathbf{2}$ & $\begin{array}{c}\text { Colombia } \\
\text { (Río Negro) }\end{array}$ \\
\hline (Pie de Monte/Putumayo)
\end{tabular}


of $x$. W

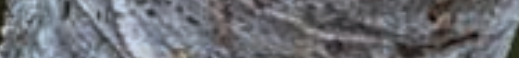


As for amphibians and birds, this analysis contrasts the number of mammals reported with the number of mammals expected in each of the landscapes. The expected mammal numbers are the result of distribution data extracted from the IUCN (2019), combined with the boundary polygons of each Andes-Amazon landscape supported by WCS. Reported mammals are based on confirmed records extracted from different bibliographic sources and data sent by each program.

Madidi-Tambopata Landscape. IUCN (2019) data estimates that 316 mammal species are present in this landscape. So far, 253 mammal species have been confirmed in this landscape through prior research (Romo \& Emmons, 1991) and information from WCS in Bolivia and Peru, which corresponds to $80.06 \%$ of estimated mammal species for the landscape, $33 \%$ of mammals in the Amazon, $20 \%$ of those in South America, and $5 \%$ of those in the world.

Marañón-Ucayalí Landscape. We estimate 294 species of mammals for this landscape. Bibliographic references (Salovaara, 2003) and information from WCS Peru, report 233 mammal species, representing $79.25 \%$ of expected species in the landscape, $26.66 \%$ of Amazonian mammals, $16.82 \%$ of those in South America, and $3.64 \%$ of those in the world.

Yasuni Landscape. We estimate 194 mammal species (IUCN 2019) for this landscape. According to bibliography (Castro \& Román, 2000) and WCS Ecuador, 168 species are reported, representing $86.6 \%$ of estimated mammals for the landscape, $19.22 \%$ of Amazonian mammals, $12.13 \%$ of those in South America, and $2.63 \%$ of those in the world.

Pie de Monte/Putumayo Landscape. The total number of mammals expected in this landscape is 292 species. A lack of information about the number of registered species prevents the same comparisons as for other landscapes.

Rio Negro Landscape. We estimate 268 mammal species in this landscape (IUCN 2019). WCS Brazil confirmed that 172 species have been reported in the landscape, corresponding to $64.18 \%$ of estimated species for the landscape, $19.68 \%$ of Amazonian mammals, $12.42 \%$ of those in South America, and $2.69 \%$ of the mammals of the world.

Table 6 details the percentage of representativeness of each landscape at the Amazon, South America and global levels. Figure 4 shows the contrast of the reported species with the expected species in each of the landscapes 
Table 6: Number of reported and expected bird species for each of the Andes-Amazon landscapes supported by WCS and comparison of reported amphibian species with estimated bird species totals for the Amazon, South America and the world. Only expected species are included for the Pie de Monte/Putumayo landscape in Colombia.

\begin{tabular}{|c|c|c|c|c|c|c|c|c|c|c|c|c|}
\hline \multirow{2}{*}{$\begin{array}{l}\text { LANDSCAPES } \\
\text { Andes-Amazon }\end{array}$} & \multicolumn{2}{|c|}{ Madidi-Tambopata } & \multicolumn{2}{|c|}{ Marañón Ucayali } & \multicolumn{2}{|c|}{ Yasuní } & \multicolumn{2}{|c|}{ Pie de Monte/Putumayo } & \multicolumn{2}{|c|}{ Río Negro } & \multicolumn{2}{|c|}{ Landscapes Total } \\
\hline & Reported & Expected & Reported & Expected & Reported & Expected & Reported & Expected & Reported & Expected & Reported & Expected \\
\hline $\begin{array}{l}\text { Number of reported and } \\
\text { expected bird species in each } \\
\text { landscape }\end{array}$ & 253 & 316 & 233 & 294 & 168 & 194 & - & 292 & 172 & 268 & 449 & 557 \\
\hline $\begin{array}{l}\text { Percentage of expected birds } \\
\text { reported in the landscape }\end{array}$ & \multicolumn{2}{|c|}{$80.06 \%$} & \multicolumn{2}{|c|}{$79.25 \%$} & \multicolumn{2}{|c|}{$86.6 \%$} & \multicolumn{2}{|c|}{ - } & \multicolumn{2}{|c|}{$64.18 \%$} & \multicolumn{2}{|c|}{$81 \%$} \\
\hline $\begin{array}{l}\text { Percentage of mammal species } \\
\text { in the Amazon ( } 874 \text { species) }\end{array}$ & $28.94 \%$ & $36.16 \%$ & $26.66 \%$ & $33.64 \%$ & $19.22 \%$ & $22.2 \%$ & - & $33.41 \%$ & $19.68 \%$ & $30.66 \%$ & $51.37 \%$ & $63.73 \%$ \\
\hline $\begin{array}{l}\text { Percentage of mammal species } \\
\text { in South America ( } 1,385 \text { species) }\end{array}$ & $18.26 \%$ & $22.82 \%$ & $16.82 \%$ & $21.23 \%$ & $12.13 \%$ & $14.01 \%$ & - & $21.08 \%$ & $12.42 \%$ & $19.35 \%$ & $32.42 \%$ & $40.22 \%$ \\
\hline $\begin{array}{l}\text { Percentage of mammal species } \\
\text { in the world }(6,399 \text { species })\end{array}$ & $3.95 \%$ & $4.94 \%$ & $3.64 \%$ & $4.59 \%$ & $2.63 \%$ & $3.03 \%$ & - & $4.56 \%$ & $2.69 \%$ & $4.19 \%$ & $7.02 \%$ & $8.7 \%$ \\
\hline
\end{tabular}

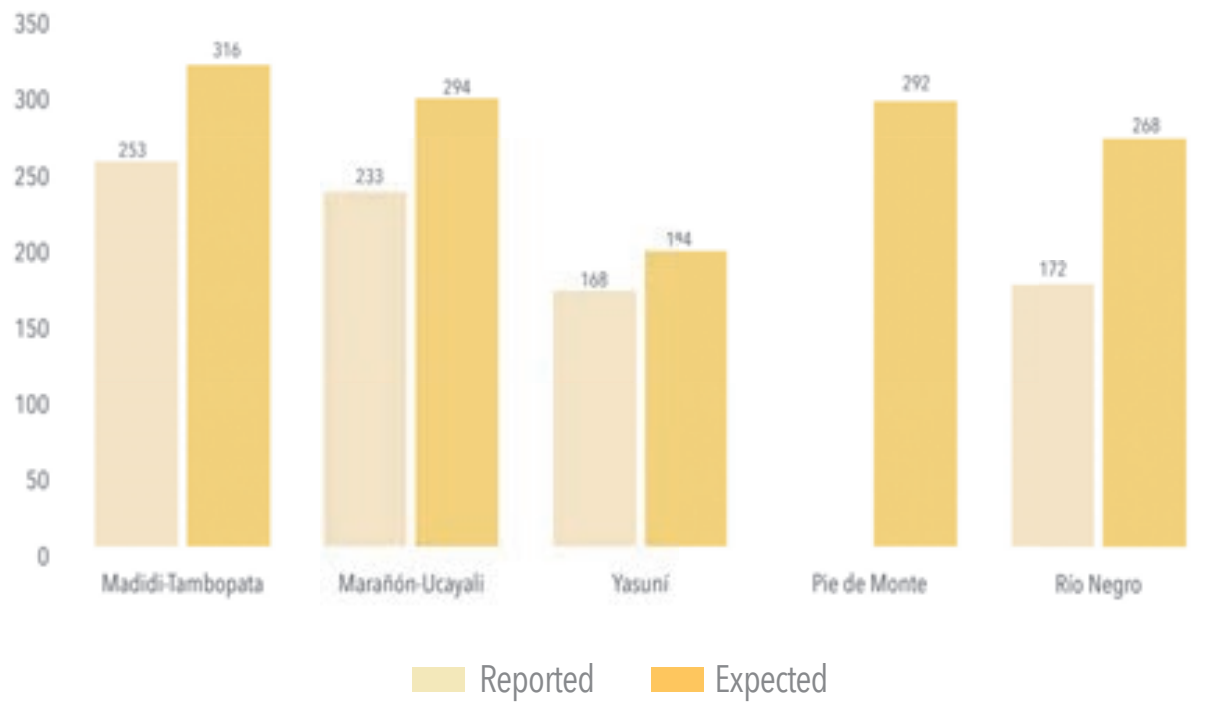

Figure 4: Number of reported and expected mammal species for each of the Andes-Amazon landscapes supported by WCS. Only expected species are included for the Pie de Monte/Putumayo landscape in Colombia. 


\section{The Importance of Landscapes for Biodiversity Conservation}

Collectively, within the suite of Andes-Amazon landscapes supported by WCS, $76.76 \%$ of the estimated species of birds, mammals and amphibians have already been registered, representing almost $9 \%$ of the worldwide species diversity of these three groups of vertebrates, $30.4 \%$ of South American species, and $47.12 \%$ of Amazonian species. Using expected species, the five Andes-Amazon landscapes supported by WCS hold approximately $11 \%$ of the worldwide species diversity of these three groups of vertebrates, representing $37 \%$ of South American species, and 61\% of Amazonian species (Table 7 and Figure 5).

For amphibians, the reported species analysis shows that the set of Andes-Amazon landscapes supported by WCS hosts approximately 19\% of Amazonian amphibian species, $9 \%$ of those in South America, and 3.3\% of those in the world. For expected amphibian species, these percentages double to 38\% of Amazonian species, $17 \%$ of those in South America, and $6 \%$ of those worldwide.

Reported bird species in the set of landscapes amount to $61 \%$ of birds registered in the Amazon, $42 \%$ of those registered in South America, and $14 \%$ of known species in the world. Expected species analyses increase these percentages to $73 \%$ of the birds of the Amazon, $51 \%$ of those of South America, and $17 \%$ of global species.

Table 7.A comparison of the total number of species of amphibians, birds and mammals reported and expected species across all landscapes, as well as comparisons with the number of expected in species in the Amazon, South America and the world. Only expected species are included for the Pie de Monte/Putumayo landscape in Colombia.

\begin{tabular}{|c|c|c|c|c|c|}
\hline & Reported Species & Expected Species & $\begin{array}{l}\text { Total Species } \\
\text { Andes-Amazon }\end{array}$ & $\begin{array}{c}\text { Total Species South } \\
\text { America }\end{array}$ & Total Species Global \\
\hline Amphibians & 264 & 508 & 1,350 & 2,921 & 8,018 \\
\hline Birds & 1,514 & 1,836 & 2,502 & 3,607 & 11,126 \\
\hline Mammals & 449 & 557 & 874 & 1,385 & 6,399 \\
\hline Total & 2,227 & 2,901 & 4,726 & 7,913 & 25,543 \\
\hline $\begin{array}{l}\text { Collective landscape contribution } \\
\text { for reported species }\end{array}$ & \multirow{2}{*}{\multicolumn{2}{|c|}{$76.76 \%$ confirmed species }} & $47.12 \%$ & $30.4 \%$ & $8.71 \%$ \\
\hline $\begin{array}{l}\text { Collective landscape contribution } \\
\text { for expected species }\end{array}$ & & & $61.38 \%$ & $36.66 \%$ & $11.36 \%$ \\
\hline
\end{tabular}



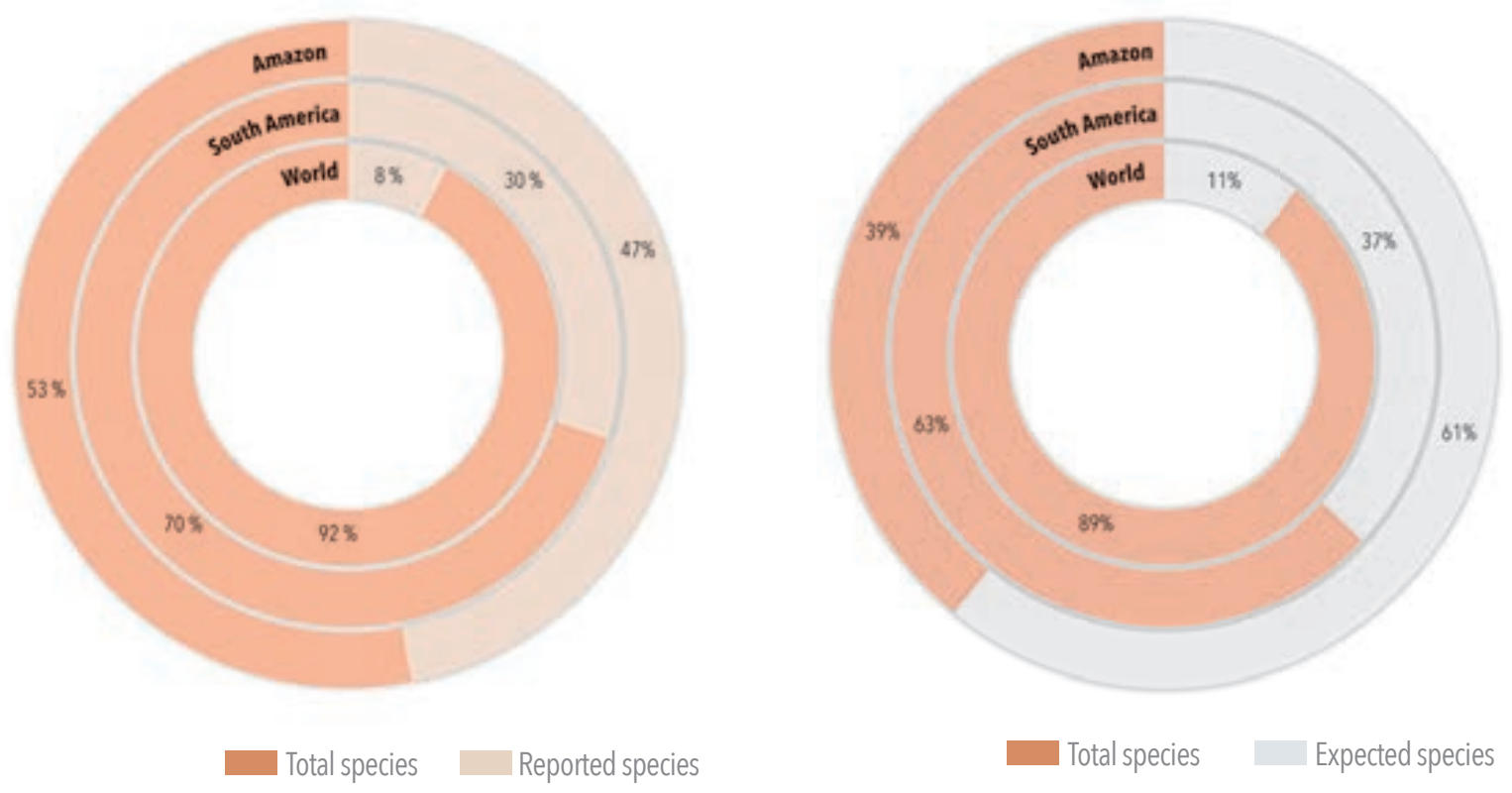

Figure 5. Percentage of reported (left) and expected (right) species for three combined vertebrate groups in the Andes-Amazon landscapes supported by WCS, according to total species for these groups in the Amazon, South America and the world.

Reported mammals in the Andes Amazon landscapes supported by WCS constitute 51\% of mammals registered in the Amazon, $32 \%$ of those registered in South America, and 7\% of those registered in the world. Expected mammals in the landscapes amount to $64 \%$ of Amazonian species, $40 \%$ of those in South America; and $9 \%$ of global mammal species.

These figures highlight the extraordinary biodiversity conservation relevance of the five conservation landscapes which WCS supports in the Andes-Amazon, and the protected areas and indigenous territories therein (Wallace et al., 2020a). While the comparison of the number of confirmed versus expected species (Figure 6) underlines the need for further research to address information gaps at each site.

Protected areas host an enormous biodiversity including a diversity of plants, fungi, invertebrates, fish, amphibians, reptiles, birds, and mammals, and also fulfill ecological functions and provide environmental services essential to the life of human communities. In the AndesAmazon, protected areas contribute to the regulation of climate due to the large extensions of tropical rainforest, thus maintaining stable climatic conditions (Killeen etal.,2007). 
a.

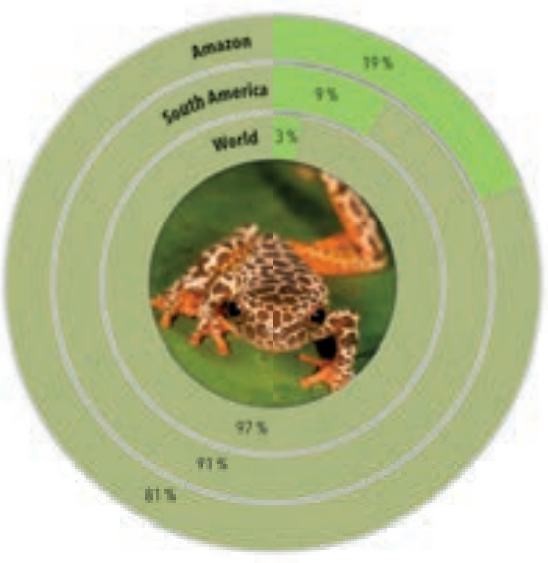

Total species Reported species

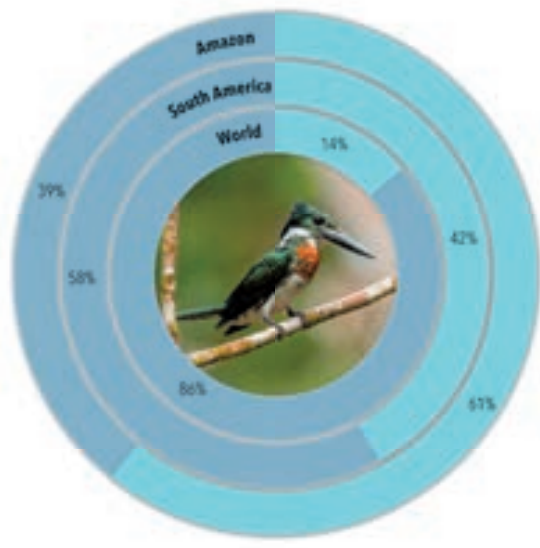

Total species Reported species

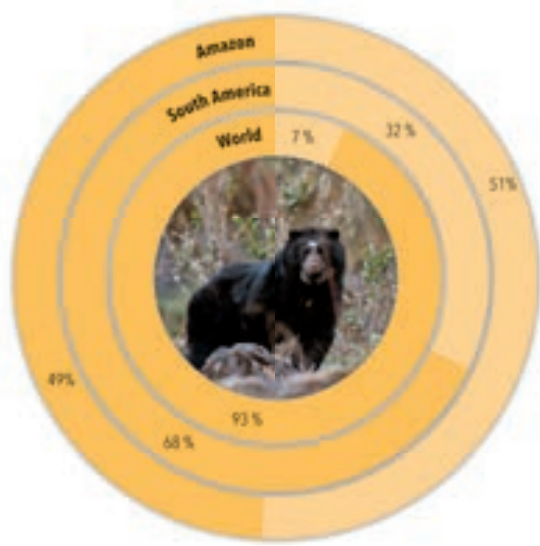

Total species h

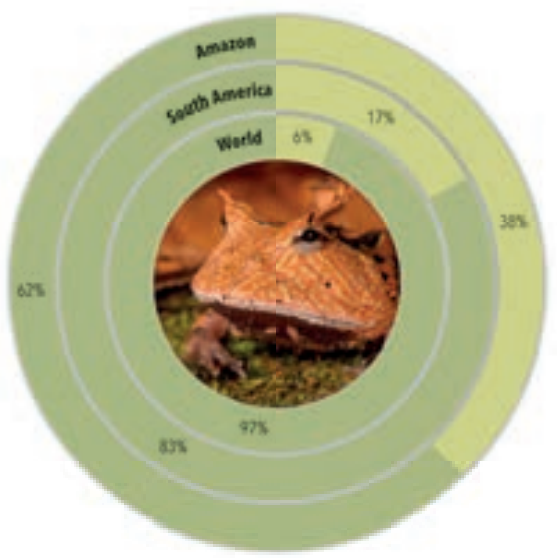

Total species $\quad$ Expected species

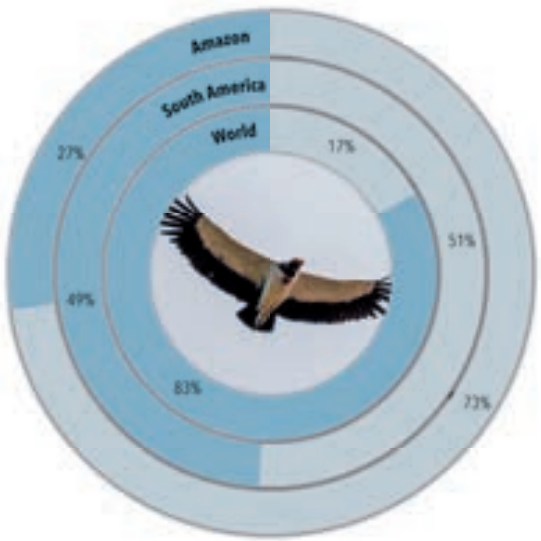

Total species _ Expected species

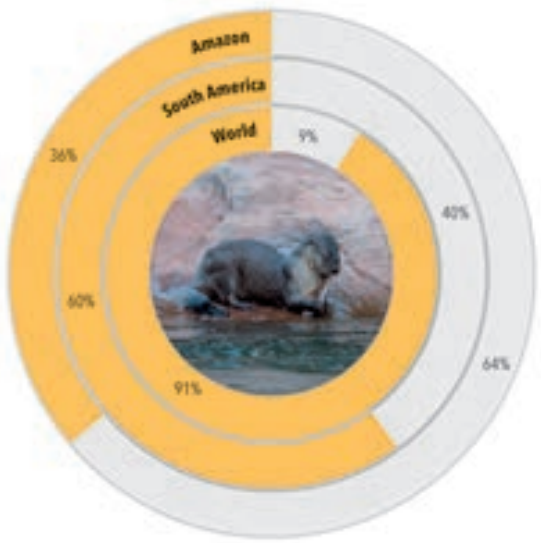

Total species Expected species

Figure 6. Percentage of reported (left) and expected (right) species for each of three vertebrate groups in the Andes-Amazon landscapes supported by WCS, according to total species for these groups in the Amazon, South America and the world. 
Indigenous territories also represent significant biodiversity conservation value (Wallace et al., 2020a), especially given the coexistence relationship between Indigenous People and nature, especially with regard to forest services. These areas compliment national and subnational protected areas in the Amazon (ECLAC, 2013), protecting large swathes of tropical forest whilst also contributing to biodiversity conservation and providing opportunities to improve local livelihoods through natural resource management.

Tropical forests are home to most of the world's terrestrial biodiversity, however, high deforestation rates and loss of fauna, particularly large mammals, cause direct and indirect negative effects on biodiversity and the biological functions of a diversity of ecosystems (Paviolo, 2016). For the conservation of the Amazon rainforest, each country has different regulations that protect these territories, in which they define a property right regulated by the State and with actions aimed at their protection. The Andes-Amazon landscapes that WCS supports cover 56 million hectares, representing 7.06\% of the Amazon (Madidi-Tambopata: 1.78\%; Marañón-Ucayalí: 2.12\%; Yasuní: 0.61\%; Pie de Monte/ Putumayo: 0.43\%; Río Negro: 2.14\%). 


\section{The Importance of Landscape Species in the Andes-Amazon}

Landscape species have large spatial requirements that can contribute to defining the size and shape of areas that need to be managed for conservation. These species are considered as indicators of the conservation status and health of the natural environment. They also requirea wide variety of habitats to meet their ecological needs, since they use large areas and have a significant impact on the structure and function of ecosystems. They are an important tool for conservation planning, since they play fundamental roles in the design and implementation of conservation strategies. Thus, landscape species can be considered as a set of "umbrella species" (Wallace \& Siles, 2011).

Typically, landscape species meet the following criteria: they represent an umbrella species for the rest of biodiversity, they range at a landscape scale, they are useful as an indicator species in the face of threats, and they play the role of a keystone species from the perspective of ecological functions(Sanderson et al., 2002; Figueroa, 2016). In theAndes-Amazon there are several obvious landscape species including the Andean condor (Vultur gryphus), the Andean bear (Tremarctos ornatus), the jaguar (Panthera onca), the white-lipped peccary (Tayassu pecari), the lowland tapir(Tapirus terrestris) and the giant otter(Pteronura brasiliensis).

We superimposed the spatial data of the priority conservation units for five landscape species with the boundaries of the Andes-Amazon landscapes. The priority conservation units for each species were identified according to expert-driven collaborative data sets, which include: i) the current distribution of each species, ii) the historical distribution of each species, iii) areas with important populations, suitable habitat, stable populations and food resources, and finally, iv) the locations where each species have been recorded (Sanderson et al., 2002). The percentage of each landscape that overlaps with the conservation units for each species was determined (Figures 7-11), with data for five species: jaguar (Sanderson et al., 2002), Andean bear (conservation units for Peru and Bolivia) (Wallace et al., 2014), white-lipped peccary and lowland tapir (Taber et al., 2009) and Andean condor (Wallace et al., 2020b).

Large carnivores, such as the jaguar, are keystone species within tropical forests, as they maintain the balance of biodiversity and ecological processes (Paviolo, 2016). The jaguar is a classic umbrella species, requiring large areas of habitat. Effective conservation efforts for the jaguar should guarantee the health of the ecosystem, especially healthy populations of herbivores, as their main prey (Conde et al., 2010), and therefore can benefit other species that coexist with them and whose spatial needs are considerably less (Wallace \& Siles, 2011). Studies show that jaguars in the Amazon are better protected compared to other regions of the continent. The distribution of the jaguar in the Amazon covers 5.8 million $\mathrm{km}^{2}$, representing $64 \%$ of its entire range $\left(9.1\right.$ million $\left.\mathrm{km}^{2}\right)$. The identified priority jaguar conservation units (Marieb, 2006) cover an area of 1.19 million $\mathrm{km}^{2}$, of which $61 \%$ are Amazonian areas. Approximately $14 \%$ of jaguar conservation units in the Amazon overlap with the Andes-Amazon conservation landscapes that WCS supports (Figure 7), representing almost 30\% of the total area of the landscapes. 


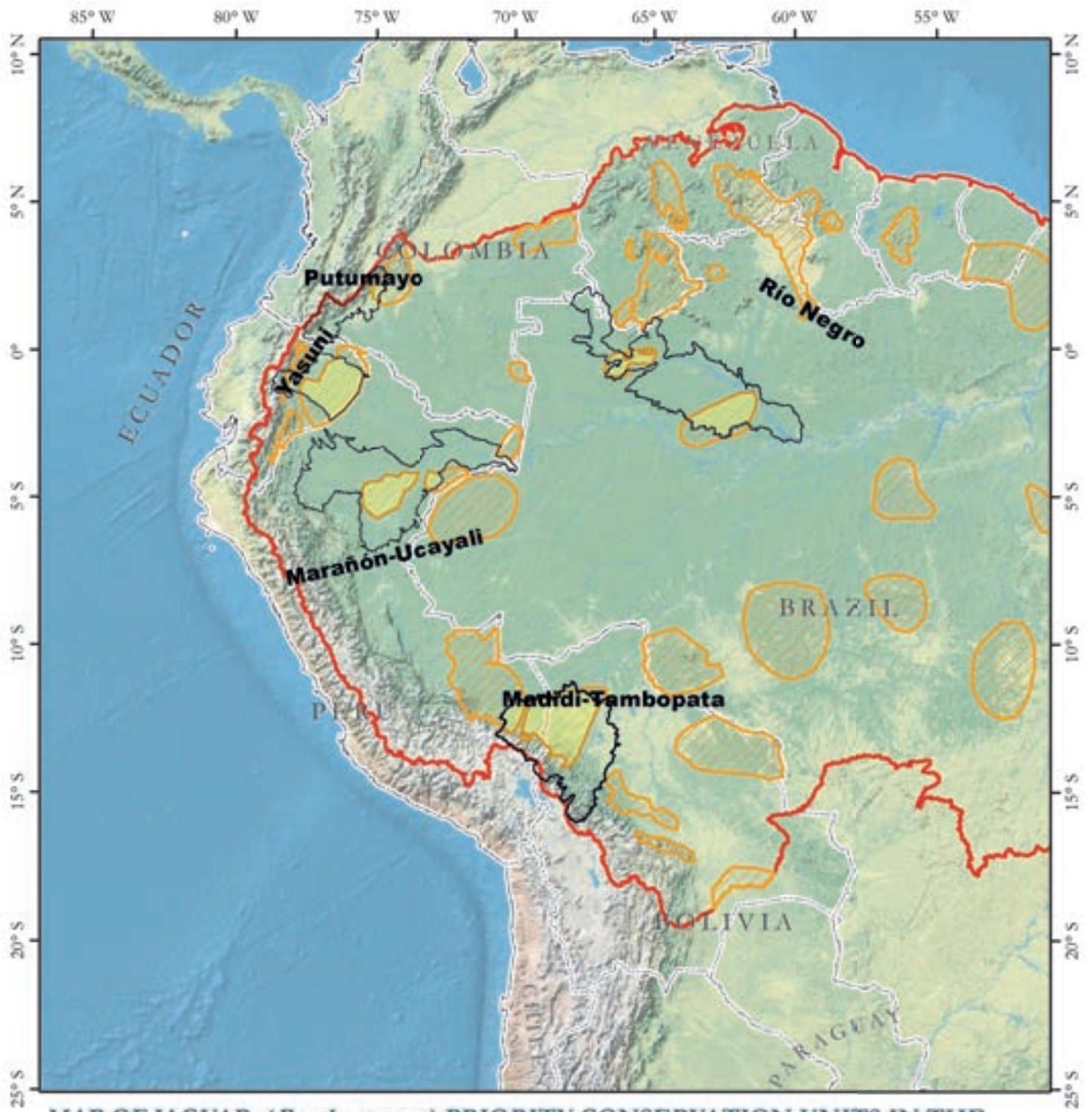

MAP OF JAGUAR (Panthera onca) PRIORITY CONSERVATION UNITS IN THE ANDES-AMAZON LANDSCAPES SUPPORTED BY WCS LEGEND

International boundaries 3 Amazon basin

3 wCS Landscapes

C3 Priority conservation units in the Andes-Amazon

C3 Priority conservation units in WCS landscapes

Overlap of Conservation Units and Landscapes

C3 Madidi-Tambopata $62,172 \mathrm{~km}^{2}$

C3 Putumayo $2,911 \mathrm{~km}^{2}$

CARTOGRAPHIC.INFORMATION

3 Rio Negro $35,389 \mathrm{~km}^{2}$

C 3 Yasuni $34,312 \mathrm{~km}^{2}$

C3 Maranón-Ucayali $26,480 \mathrm{~km}^{2}$

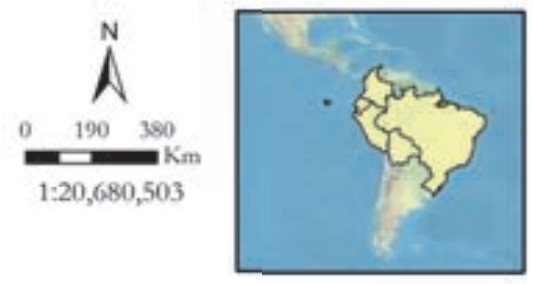

Figure 7. Map of jaguar (Panthera onca) priority conservation units in the Andes-Amazon and overlap with five landscapes supported by WCS in the Andes-Amazon. 


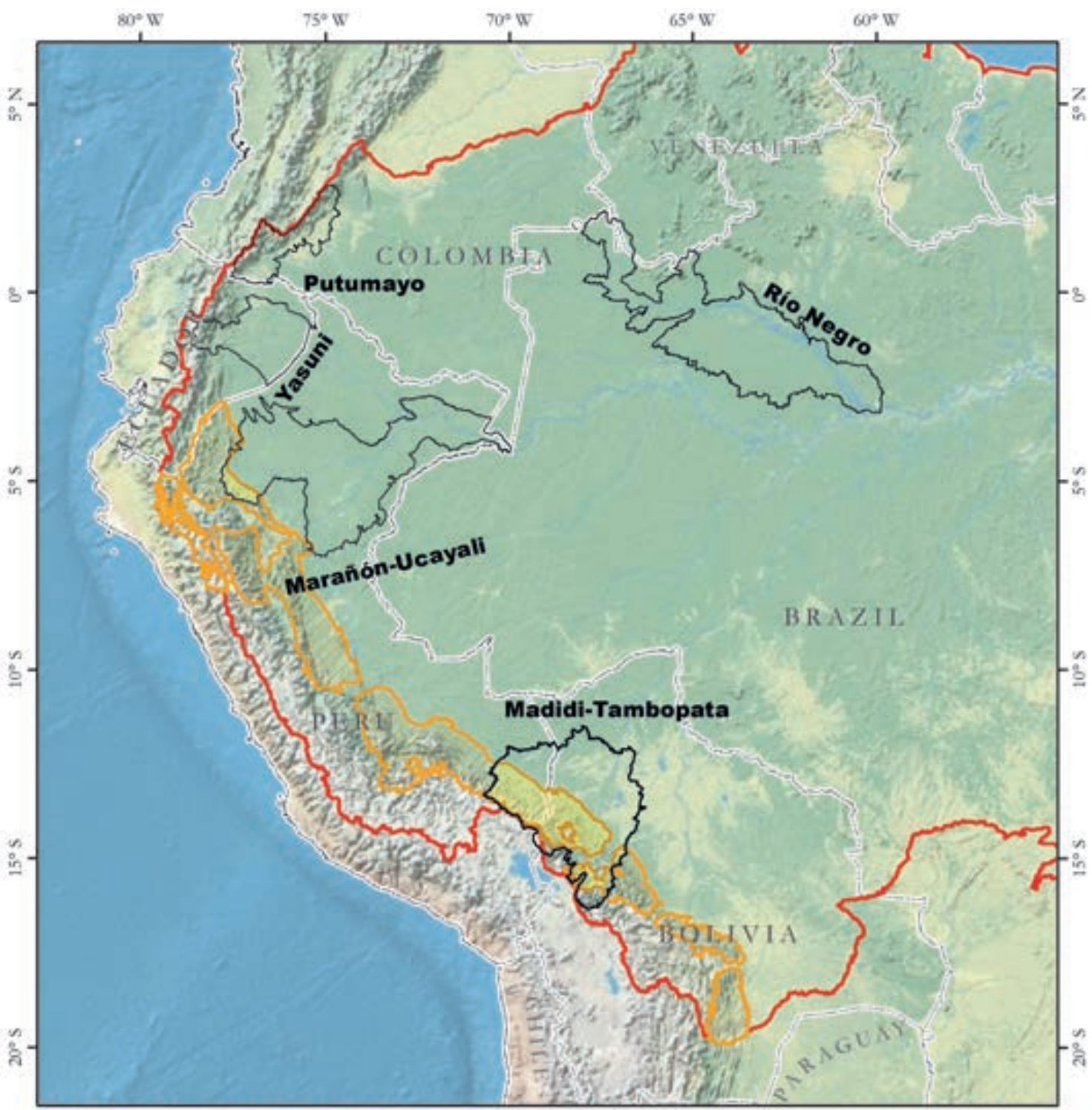

MAP OF ANDEAN BEAR (Tremarctos ornatus) PRIORITY CONSERVATION UNITS IN THE ANDES-AMAZON LANDSCAPES SUPPORTED BY WCS

\section{LEYENDA}

International boundaries 3 Amazon basin

3 WCS Landscapes

C3 Prionity conservation units in the Andes-Amazon

C3 Priority conservation units in WCS landscapes

Overlap of Conservation Units and Landscapes

C3 Madidi-Tambopata $51,740 \mathrm{~km}^{2}$

C3 Putumayo -

C3 Rio Negro -

3 Yasuni -

C3 Marañôn-Ucayali $6,161 \mathrm{~km}^{2}$
CARTOGRAPHIC INFORMATION

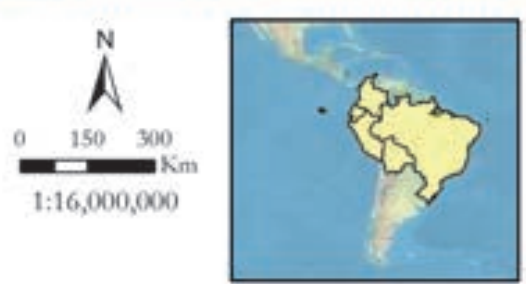

Figure 8. Map of Andean bear (Tremarctos ornatus) priority conservation units in the Andes-Amazon and overlap with five landscapes supported by WCS in the Andes-Amazon. 


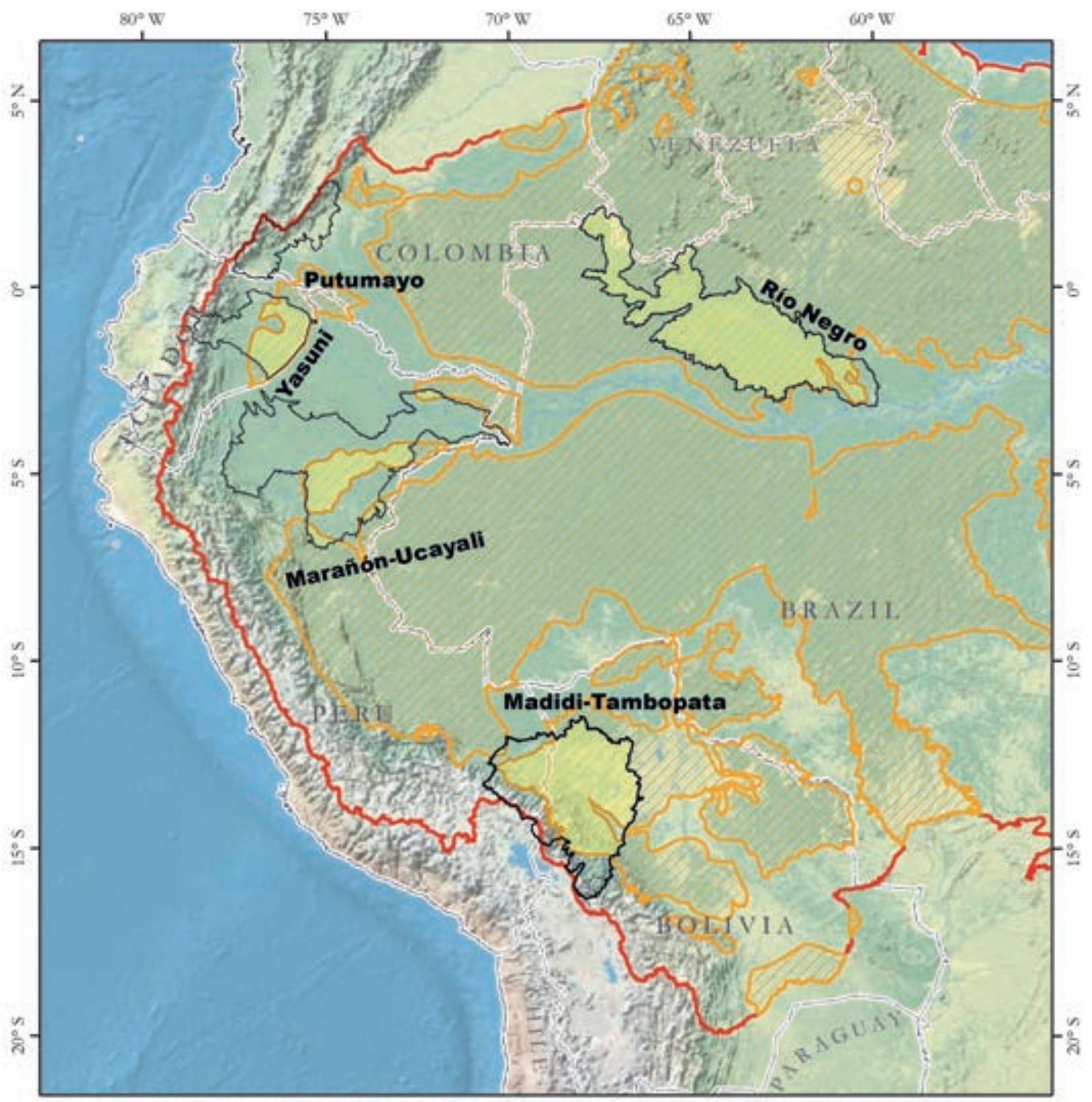

MAP OF WHITE-LIPPED PECCARY (Tayassu pecar) PRIORITY CONSERVATION UNITS IN THE ANDES-AMAZON LANDSCAPES SUPPORTED BY WCS

\section{LEGEND}

International boundaries $\sum$ Amazon basin

C3 WCS Landscapes

C3 Prority conservation units in the Andes-Amazon

C3 Prionity conservation units in WCS Landscapes Overlap of Conservation Units and Landscapes

$\checkmark 3$ Madidi-Tambopata $99,762 \mathrm{~km}^{2}$

$\checkmark 3$ Putumayo -

3 Rio Negro $161,961 \mathrm{~km}^{2}$

C3 Yasuni $24,982 \mathrm{~km}^{2}$

\3arañón-Ucayali $38,817 \mathrm{~km}^{2}$

\section{CARTOGRAPHIC INFORMATION}

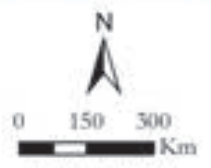

$1: 16,000,000$

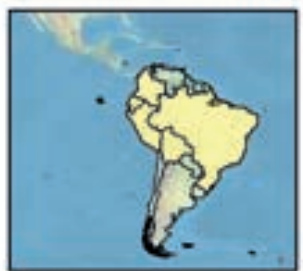

Figure 9. Map of white-lipped peccary (Tayassu pecari) priority conservation units in the Andes-Amazon and overlap with five landscapes supported by WCS in the Andes-Amazon. 


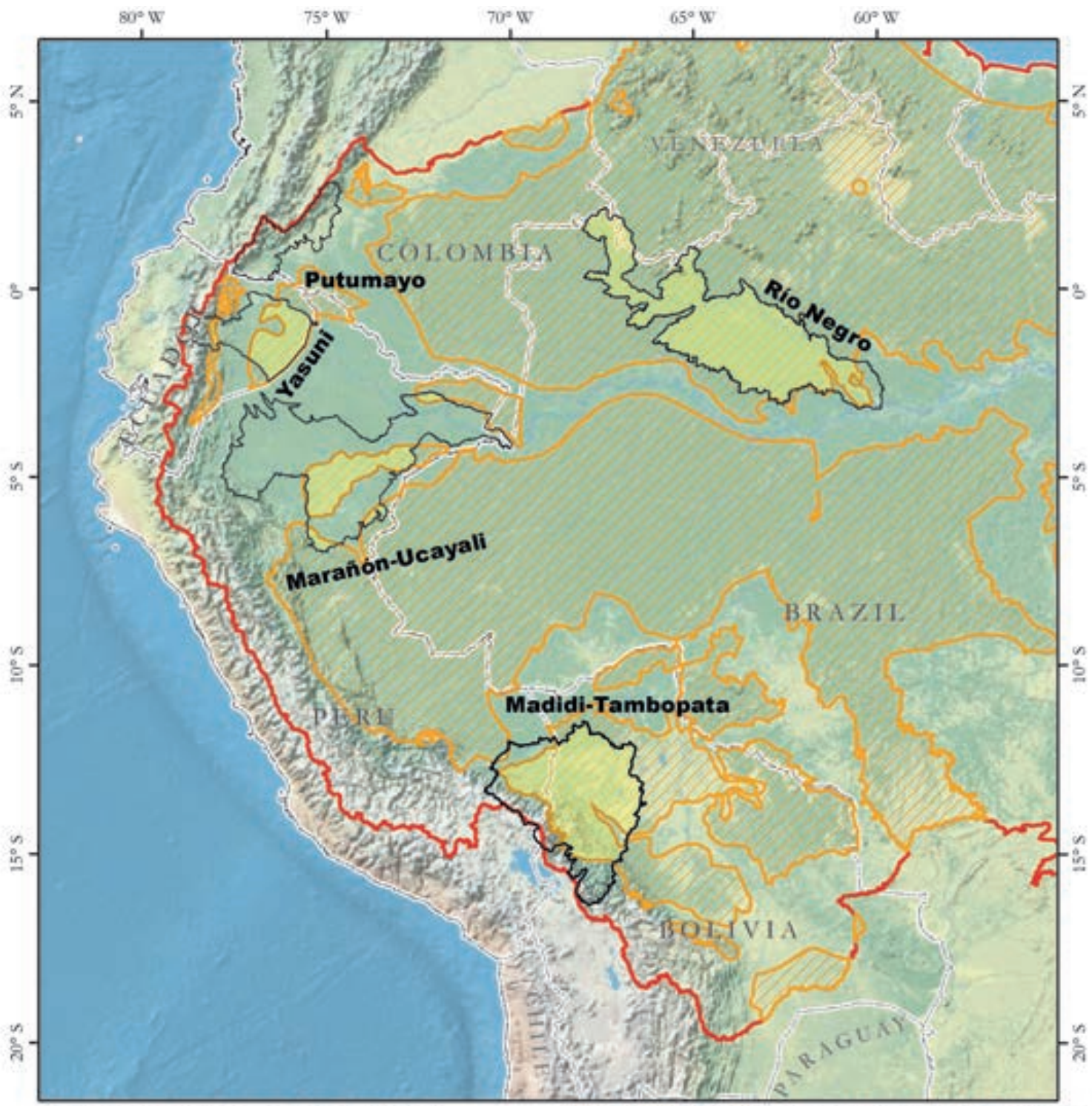

MAP OF LOWLAND TAPIR (Tapirus terrestris) PRIORITY CONSERVATION UNITS IN THE ANDES-AMAZON LANDSCAPES SUPPORTED BY WCS

\section{L.EGEND}

International boundaries 23 Amazon basin

W WCS 1 andscapes

C3 Prionity conservation units in the Andes-Amazon

C3 Prionity conservation units in WCS landscapes

\section{Overlap of Conservation Units and Landscapes}

$\sim 3$ Madidi-Tambopata $99,762 \mathrm{~km}^{2}$

C3 Putumayo --

$\widetilde{C}$ Rio Negro $161,932 \mathrm{~km}^{2}$

3 Yasuni $26,369 \mathrm{~km}^{2}$

3 Marañỏn-Ucavali $38.817 \mathrm{~km}^{2}$

\section{CARTOGRAPHIC INFORMATTON}
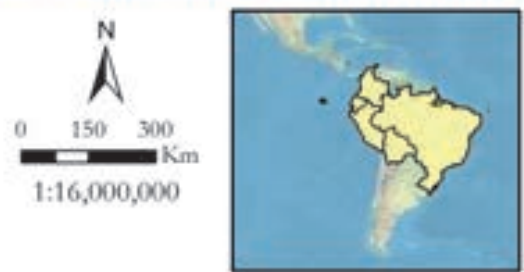

Figure 10. Map of lowland tapir (Tapirus terrestris) priority conservation units in the Andes-Amazon and overlap with five landscapes supported by WCS in the Andes-Amazon. 


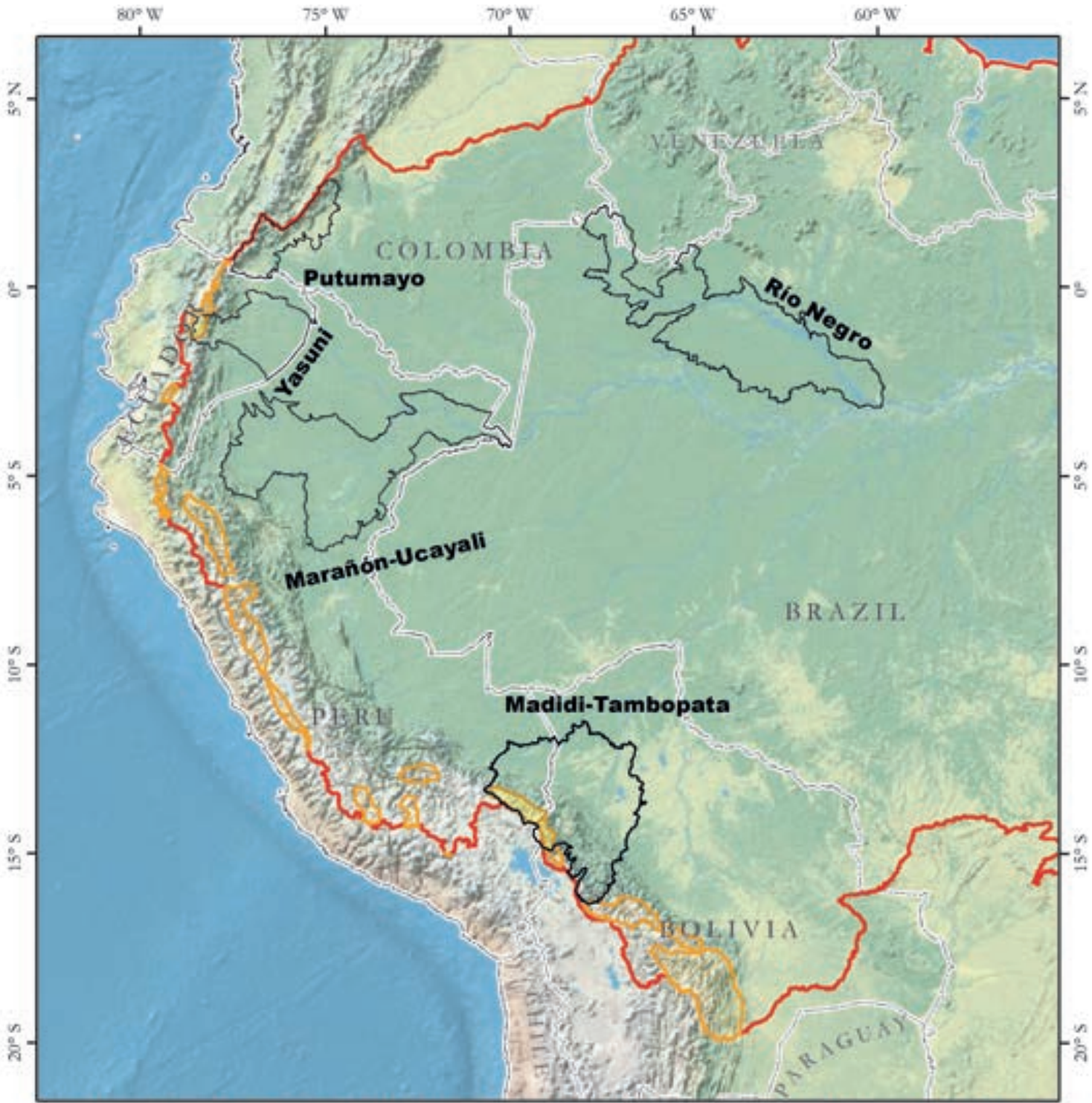

MAP OF ANDEAN CONDOR (Vultur gryphus) PRIORITY CONSERVATION UNITS IN THE ANDES-AMAZON LANDSCAPES SUPPORTED BY WCS

\section{L.EGEND}

International boundaries 3 Amazon basin

C3 WCS Landscapes

3 Priority conservation units in the Andes-Amazon

C3 Priority conservation units in WCS landscapes Overlap of Conservation Units and Landscapes

3 Madidi-Tambopata $9,230 \mathrm{~km}^{2}$

3 Putumayo --

3 Rio Negro -

$\widetilde{C}$ Yasuni $-1,938 \mathrm{~km}^{2}$

C 3 Marañón-Ucayali -
CARTOGRAPHIC INFORMATION
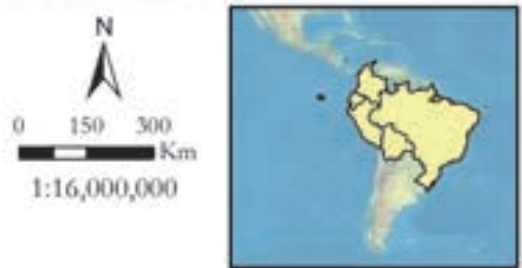

Figure 11. Map of Andean condor (Vultur gryphus) priority conservation units in the Andes-Amazon and overlap with five landscapes supported by WCS in the Andes-Amazon. 
The Andean bear is a charismatic and threatened species that needs large areas of Andean montane forest, so it has the characteristics of a landscape species, and has been used as a criterion for planning protected wilderness areas in tropical and subtropical Andean ecosystems (Peyton, 1999). The Andean bear is Vulnerable (IUCN, 2020), endemic to the tropical Andes and is the only bear species found in South America. The range of this species is approximately $309,000 \mathrm{~km}^{2}$, which overlaps with the Amazon basin. The analysis of Andean bear conservation units for Bolivia and Peru defines a total area of $328,000 \mathrm{~km}^{2}$ (Wallace et al., 2014), of which $15.77 \%\left(51,740 \mathrm{~km}^{2}\right)$ overlap with the Andes-Amazon landscapes supported by WCS, specifically the Greater Madidi-Tambopata Landscape (Figure 8).

The lowland tapir is also considered a landscape species as a seed disperser it contributes to the maintenance of the ecosystems in which it lives. Tapirs require relatively large home range areas. The lowland tapir is Vulnerable (IUCN, 2020), with a decreasing population trend. The total area of its distribution is 13 million $\mathrm{km}^{2}$ (Taber et al., 2009), with the Amazon reaching 59\% of that distribution (7.69 million km²). Tapir conservation units cover 5 million $\mathrm{km}^{2}$ including 326,881 km² (7.17\%) within the conservation landscapes supported by WCS (Figure 9), representing $57.3 \%$ of the total area of the landscapes.

The white-lipped peccary is one of the most important wildlife species of the Amazon. A classic landscape species, with white-lipped peccary herds requiring extensive areas for their home ranges, and fulfilling fundamental ecosystem functions as seed consumers and ecological engineers, it is also a major source of protein for indigenous and local communities that rely on subsistence hunting for food security. Whitelipped peccaries are Vulnerable (IUCN, 2020), and populations are decreasing due to illegal hunting and habitat loss. It is an omnivorous species, consuming fruits, roots, tubers, herbs, small vertebrates and invertebrates. Its distribution in the Amazon reaches 7.5 million $\mathrm{km}^{2}$ (Taber et al., 2009), representing 43\% of its total distribution (17.6 million $\mathrm{km}^{2}$ ).About $7.4 \%$ of white-lipped peccary conservation units $\left(325,523 \mathrm{~km}^{2}\right)$ in the Amazon overlap with the Andes-Amazon conservation landscapes that WCS supports (Figure 10), representing 57.2\% of the total area of the landscapes.

The Andean condor is another a landscape species, playing a fundamental ecological role as a scavenger, accelerating the decomposition process of dead animals and thus reducing the risk of diseases associated with carcasses. A regionally significant population of condors is found within the Madidi-Tambopata landscape (Rios-Uzeda \& Wallace, 2006). Despite its important ecological function in the Andean Amazon ecosystem, this species faces various threats, including indiscriminate hunting, lead contamination and illegal carrion poisoning (Wallace et al., 2020b). According to the IUCN (2020), this species is native to Argentina, Bolivia, Chile, Colombia, Ecuador, Peru and Venezuela. The total area of distribution of the Andean condor covers 3.2 million km² (Wallace et al., 2020b). Its range in the Andes-Amazon covers $454,000 \mathrm{~km}^{2}$ (representing $14 \%$ of the total range). Finally, the conservation units of this species cover $329,000 \mathrm{~km}^{2}$, with the landscapes thatWCS supports containing $3 \%$ of these units $\left(11,169 \mathrm{~km}^{2}\right)$, distributed mainly in the Greater Madidi-Tambopata and Yasuni landscapes (Figure 11). 
The giant otter is the largest otter in the world, but is considered Endangered (IUCN 2020), as it is sensitive to changes and alterations in aquatic habitats, and is generally found in sites where there are low levels of disturbance, and may be an indicator of the health status of certain habitats (Zambrana et al. 2009). In addition, it is territorial, requiring large stretches of rivers and adjacent ox-bow lakes, and feeding on several fish species. Giant otter distribution covers a total area of 6,6 million km², $94 \%$ of which is found in the Amazon basin (approximately 6,2 million km²). Studies of the giant otter in the Madidi-Tambopata (van Damme et al., 2003), Marañón-Ucayalí (Aquino et al., 2001) and Yasuní (Fernsen, 1997; Utreras \& Pinos, 2003) landscapes can be used as a baseline for the development of conservation strategies for this species at the landscape and regional (Amazon) scales.

The marsh deer (Blastocerus dichotomus) is the largest deer in South America, and inhabits wetland savannas. It is considered Vulnerable by the IUCN (2020), due to habitat destruction, hunting, and the spread of diseases caused by domestic animals (Ríos-Uzeda \& Ayala, 2009). This species is present in the Madidi-Tambopata landscape (Rios-Uzeda \& Mourão, 2012). The distribution of this species in the Amazon represents approximately $37 \%$ of its total distribution (4 million $\mathrm{km}^{2}$ ).

Three species of river dolphins are found in the Amazon basin (Inia geoffrensis, Inia boliviensis and Sotalia fluviatilis). These species live in the main rivers, tributaries and lagoons, and even in flood areas. They are top predators in these aquatic systems. However, these dolphins and aquatic habitats are threatened by human activities such as fishing, deforestation, habitat fragmentation and water pollution (Trujillo et al., 2010). These aquatic species provide a lens for the development of conservation strategies using an integrated watershed management approach in the Amazon and Orinoco rivers.

In short, the Andes-Amazon landscapes that WCS supports are also key for the conservation of some of the most important stronghold populations of the most charismatic species of the region, including the Andean condor as the symbol of the High Andes, the Andean bear as the ambassador for Andean cloud forests, and the jaguar as the wildlife icon of the Amazon. 


\section{RECOMMENDATIONS}

This pioneering systematization of the biological diversity of three groups of vertebrates present in the landscapes that WCS supports in the Andes-Amazon, demonstrates their importance for biodiversity conservation and highlights the conservation efforts that the Wildlife Conservation Society develops in the Andes Amazon region. This information could be the baseline for estimating the biological diversity of other landscapes and conservation programs supported by WCS, such as in the Orinoco, Patagonia, Central America, and the western Caribbean.

The information gathered from different sources offers more detailed information about the characteristics of the species that each landscape hosts, categorizing them according to their different attributes, such as:

- Identifying strictly Amazonian species, mostly Amazonian species, or species mostly from other areas but which also occur in the Amazon, or which strictly belong to other areas.

- Determine the number of threatened species for each landscape.

- Determine species endemism for each landscape.

- Identify potential biodiversity hotspots within each landscape using the information from the three groups of vertebrates to establish the greatest concentration of species for each group, and the three groups of vertebrates combined.

The systematized information has already been used to evaluate the contribution of protected areas and indigenous territories to the conservation of Amazonian biodiversity (Wallace et al.2020a), and the action portfolios of other important actors in the Amazon, such as the Gordon and Betty Moore Foundation (Wallace et al. 2020b).

Finally, in the future it would be ideal to include and complement this analysis with information from the other groups of vertebrates (reptiles and fish), as well as other branches of biodiversity, such as plants and butterflies. 


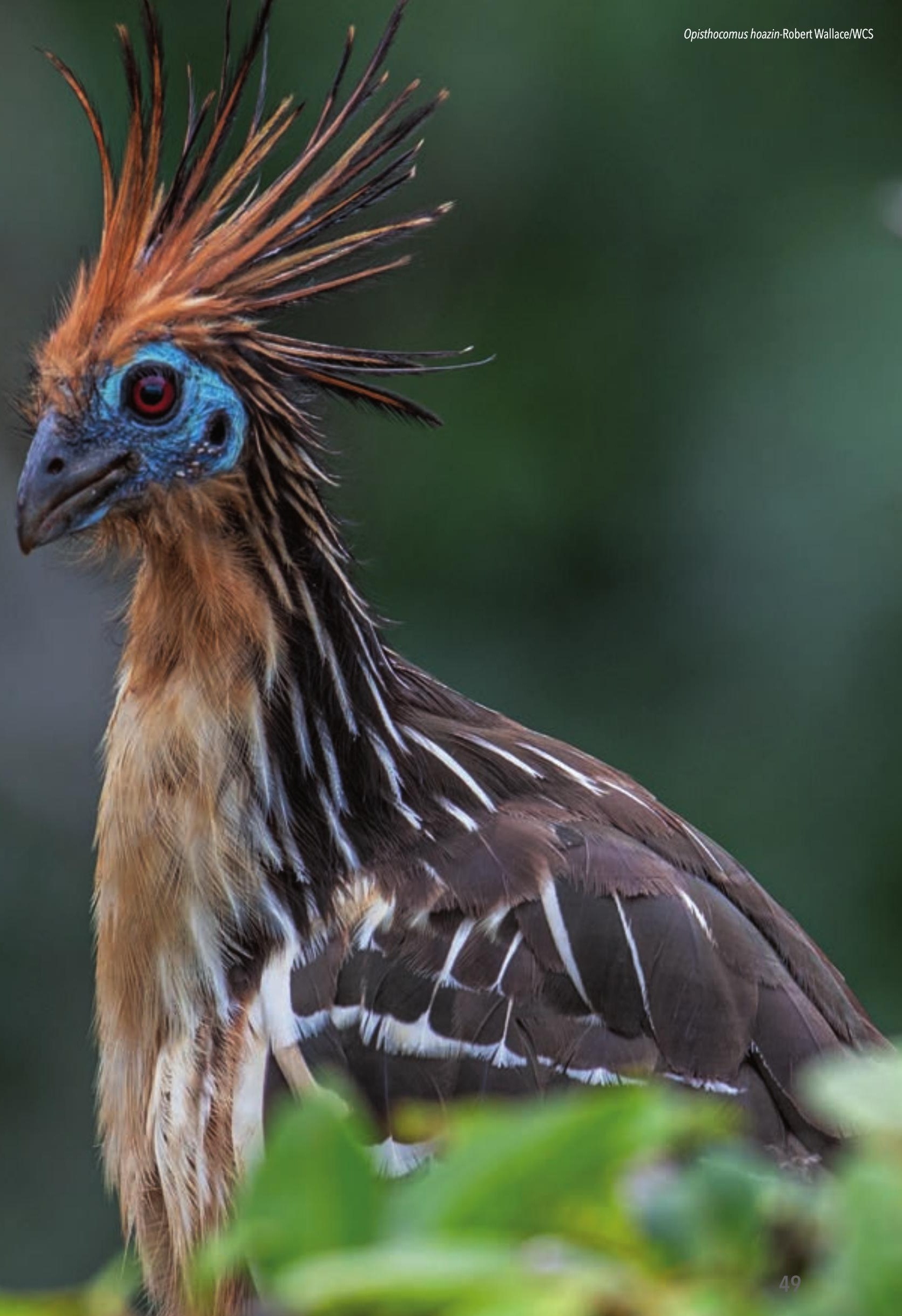




\section{REFERENCES}

- Achard F, DeFries R, Eva H, Hansen M, Mayaux P \& Stibig HJ. 2007. Pan-tropical monitoring of deforestation. Environmental Research Letters 2:045022.

- AmphibiaWeb (2019). http://amphibiaweb.org. University of California, Berkeley, CA, USA. Accessed 20 March 2018

- Amphibian species of the world: an online reference. Version $6.0 \mathrm{http}: / /$ research.amnh.org/herpetology/ amphibia/index.html. American Museum of Natural History, New York, USA. Accessed 7 Nov 2018

- Aquino R, Bodmer, \& Hil J. 2001. Mamíferos de la cuenca del río Samiria: Ecología poblacional y sustentabilidad de la caza. Wildlife Conservation Society, Programa Samiria, Lima, Perú, 116 pp.

- $\quad$ Avibase. The World Bird Database. https://avibase.bsceoc.org/. Accessed on November 2016.

- Benitez V, Sanchez D \& Larrea M. 2000. Evaluación ecológica rápida de la avifauna en el Parque Nacional Llanganates. In: Vásquez MA, Larrea M \& Suarez L (Eds) Biodiversidad en el Parque Nacional Llanganates: Un Reporte de las Evaluaciones Ecológicas y Socioeconómicas Rápidas. EcoCiencia, Ministerio de Medio Ambiente, Herbario Nacional del Ecuador, Museo Ecuatoriano de Ciencias Naturales \& Instituto Internacional de Reconstrucción Rural Quito.

- Betancourth-Cundar, M. 2010. Aspectos ecológicos de la herpetofauna del centro experimental amazónico, Putumayo, Colombia. Ecotrópicos 23(2): 61-78.

- $\quad$ BirdLife International \& NatureServe. 2018. Bird Species Distribution Maps of the World. BirdLife International, Cambridge, UK and NatureServe, Arlington, USA.

- BuytaertW,Cuesta-Camacho F \& Tobón C. 2011. Potential impacts of climate change on the environmental services of humid tropical alpine regions. Global Ecology and Biogeography 20:19-33.

- Castro R \& Román H. 2000. Evaluación Ecológica Rápida de la Mastofauna en el Parque Nacional Llanganates. In: Vásquez MA, Larrea M \& Suarez L (Eds). Biodiversidad en el Parque Nacional Llanganates: Un Reporte de las Evaluaciones Ecológicas y Socioeconómicas Rápidas. EcoCiencia, Misterio de Medio Ambiente, Herbario Nacional del Ecuador, Museo Ecuatoriano de Ciencias Naturales \& Instituto Internacional de Reconstrucción Rural Quito.

- Cayuela L \& Granzow-de la Cerda I. 2012. Biodiversidad y conservación de bosques Neotropicales. Ecosistemas $21: 1-5$.

- Conde, D.A., Colchero, F., Zarza, H., Christensen, N.L., Jr, Sexton, J.0., Manterola, C., Chávez, C., Rivera, A., Azuara, D. \& Ceballos, G. 2010. Sex matters: modeling male and female habitat differences for jaguar conservation. Biological Conservation 143: 1980-1988.

- Domic, E, Cortez, C, Embert, D, Aparicio, J, Reichle, S, de la Riva, I \& JM Padial. 2012. Los reptiles y anfibios del Madidi. Pp. 96-111. En: Servicio Nacional de Áreas Protegidas. Conocimientos científicos y prioridades de investigación en el Parque Nacional y Área Natural de Manejo Integrado Madidi. Eds. Salinas, E.\& R. B. Wallace. La Paz, Bolivia. 176pp.

- ECLAC (Economic Commission for Latin America and the Caribbean). 2013. Amazonia posible y sostenible. Bogotá. Pp: 258.

- Emmons, L. 1990. Mammal List. In: Conservation International "RAP Working Papers 1." Alto Madidi Region. Washington DC.

- $\quad$ eBird. The Cornell lab of ornithology. www.ebird.org. Accessed on November 2016.

- Emmons L \& Romo M. Mammals of the Upper Tambopata/Távara. 1994. In: The Tambopata-Candamo 
Reserved of Southeastern Perú: A Biological Assessment.

Conservation International. Washington, DC.

- $\quad$ Fersen, L, Uteras, V, Araya, I, Dekinger, J \& Rodriguez, M. 1997. The giant otter in Ecuador. Otter Specialist Group Bulletin 14(1).

- Gardner A. 2008. Mammals of South America, Volume 1: Marsupials, Xenarthrans, Shrews, and Bats. University of Chicago Press.

- Global Biodiversity Information Facility. 2016. www.gbif. org. Accessed on November 2016.

- Groombridge B \& Jenkins MD. 2003. World Atlas of Biodiversity. University of California Press, Berkeley, California.

- Herzog SK, Terrill RS, Jahn AE, Remsen JV, Maillard OZ, García-Solíz VH, MacLeod R, Maccormick A, Vidoz JQ, Tofte CC, Slongo H. 2016. Birds of Bolivia: field guide. Asociación Armonía. Santa Cruz de la Sierra.

- Ibisch PL \& Mérida G (Eds). 2003. Biodiversidad: La Riqueza de Bolivia. Estado de Conocimiento y Conservación. Ministerio de Desarrollo Sostenible. Editorial FAN, Santa Cruz de la Sierra, Bolivia.

- IUCN 2019. The IUCN Red List of Threatened Species. Version 2019-1. http://www.iucnredlist.org.

- IUCN 2020. The IUCN Red List of Threatened Species. Version 2019-1. http://www.iucnredlist.org.

- Jiménez-Sierra C, Torres-Orozco R \& Martínez del Río P. 2016. Biodiversidad. Una Alerta. Casa del tiempo. Universidad Autónoma Mexicana. 3(36) 9-16.

- $\quad$ Killeen TJ, Douglas M, Consiglio T, Jorgensen PM \& Mejía J. 2007. Dry spots and wet spots in the Andean Hotspot. Journal of Biogeography 34(8):1357-1373.

- Lane D, Pequeño T \& Flores W. 2003. Aves observadas en tres sitios en el Río Yavarí. In: Pietman N, Vriesendorp C \& Moskovits D (Eds). Rapid Biological Inventories: Perú:
Yavarí. The Field Museum. Chicago, Illinois.

- Malhi Y \& Grace J. 2000. Tropical forest and atmospheric carbon dioxide. Trends in Ecology and Evolution 15:332337.

- Marieb, K., 2006. Jaguars in the New Millennium Data Set Update: The State of the Jaguar in 2006. Wildlife Conservation Society, New York, USA.

- Milliman J \& K Farnswoth. 2011. River Discharge to the Coastal Ocean: A Global Synthesis. Cambridge University Press, New York.

- Ortega, M. 2010. Diversidad de la herpetofauna en el centro de la Amazonía del Ecudor. Tesis de Maestría. Instituto de Ecología A.C. Veracruz, México. Pp: 150.

- Ortiz A \& Morales M. 2000. Evaluación ecológica rápida de la herpetofauna en el Parque Nacional Llanganates. In: Vásquez MA, Larrea M \& Suarez L(Eds). Biodiversidad en el Parque Nacional Llanganates: Un Reporte de las Evaluaciones Ecológicas y Socioeconómicas Rápidas. EcoCiencia, Misterio de Medio Ambiente, Herbario Nacional del Ecuador, Museo Ecuatoriano de Ciencias Naturales \& Instituto Internacional de Reconstrucción Rural Quito.

- $\quad$ Parker, 1990. Birds List. In: Conservation International "RAP Working Papers 1." Alto Madidi Region. Washington DC.

- $\quad$ Parker T, Donahue P \& Schulenberg T. 1994. Birds of the Tambopata Reserve. In: The TambopataCandamo Reserved Zone of Southeastern Perú: A Biological Assessment. Washington, DC: Conservation international, 184.

- Patton JL, Pardiñas U \& D'Elía G. 2015. Mammals of South America Volume 2: Rodents. The University of Chicago, Chicago, USA.

- Paviolo A, De Angelo C, Ferraz K, Morato R, Martinez $P$, Srbek-Araujo A, De Mello B, Lima F, Sana D, Da Silva M, 
Velázquez M, Cullen L, Crawshaw P, Jorge ML, Galetti P, DiBitetti M, Cunha de Paula R, Eizirik E, Mitchell A, Cruz P, Perilli M, Souza A, Costa S, Moraes E \& Azevedo F. 2016. A biodiversity hotspot losing top predator: The challenge of jaguar conservation in the Atlantic Forest of South America. Scientific Reports 6: 37147.

- Peyton B. 1999. Spectacled bear conservation action plan. Pp. 157-198 In: Bears: Status Survey and Conservation Action Plan. Servheen C, Herrero S \& Peyton, B (Eds). UICN/SSC Bear Specialist Group, Gland, Switzerland \& Cambridge, United Kingdom.

- $\quad$ Ríos Uzeda B. \& Ayala, J. 2009. Blastocerus dichotomus. Mamíferos. Pp 539-541. In: Libro Rojo de Fauna Silvestre de Vertebrados de Bolivia. Ministerio de Medio Ambiente y Agua. La Paz, Bolivia.

- Ríos-Uzeda B. \& Mourão G. 2013. Densities of the vulnerable marsh deer Blastocerus dichotomus in Bolivian's northern savannahs. Oryx 46:260-265.

- $\quad$ Rodríguez L \& Knell G. 2003. Anfibios y reptiles observados durante el inventario biológico rápido en el río Yavarí: In: Pitman N, Vriesendorp C. \& Moskovits D. (Eds). Rapid Biological Inventories: Perú, Yavarí. The Field Museum, Chicago, Illinois.

- $\quad$ Romo M \& Emmons L. 1994. Mammals of the Upper Tambopata/Távara. In: Foster R, Parker T, Gentry A, Emmons L, Chicchó A, Schulember T, Rodriguez L, Lamas G, Ortega H, Icochea J, WustW, Romo M, Castillo J, Phillips O, Reynel C, Kratter A, Donhaue P \& Barkley L. (Eds). The TambopataCandamo Reserved Zone of Southeastern Perú:A Biological Assessment. Conservation International, Washington, DC.

- Sanderson E, Redford K, Chetkiewicz C, Medellin R, Rabinowitz A, Robinson J \& Taber A. 2002. Planning to save a species: the jaguar as a model. Conservation Biology 16:58-72.

- Salazar-Bravo J, Yensen E, Tarifa T \& Yates T. 2002. Distribución, historia natural y conservación de mamíferos Neotropicales. J. Neotrop. Mammal. 9(1):70-78.
- Salovaara K, Bodmer R, Puertas P, Antunez M, Montenegro 0, Reyes C \& Recharte M. 2003. Mamíferos observados y potencialmente presentes en el río Yavarí. In: Pitman N, Vriesendorp C \& Moskovits D (Eds). Rapid Biological Inventories: Perú, Yavarí. The Field Museum, Chicago, Illinois.

- $\quad$ SERNAP (Servicio Nacional de Áreas Protegidas). 2007. Plan de Manejo del área natural de manejo integrado Apolobamba. La Paz, Bolivia. Pp 102.

- SERNAP (Servicio Nacional de Áreas Protegidas) \& CRTM (Consejo Regional T'simane Mosetene). 2009. Plan de Manejo y plan de vida de la reserva de la biósfera y tierra comunitaria de origen Pilón Lajas. La Paz, Bolivia. Pp: 265.

- $\quad$ Stotz D, Pequeño T, Valdes A, Mack A, Quieroga C \& Hoke P. 2002. Lista de especies de aves registradas en las expediciones RAP en Pampas del Heath Perú 1996 y Alto Madidi Bolivia 1997. In: Reitz J (Ed). Rapid Assessment Program: Informes de las Evaluaciones Biológicas Pampas del Heath, Perú y Alto Madidi, Bolivia. Conservation International, Washington, DC.

- Taber A, Chalukian S, Altrichter M, Minkowski K, Lizárraga L, Sanderson E, Rumiz D, EdselA, de Angelo C,Antúnez M, Ayala G, Beck H, Bodmer R, Salvador B, Cartes J, de Bustos S, Eaton D, Emmons L, Estrada N, Flamarion de Oliviera L, Fragoso J, Garcia R, Gomez C, Gómez H, Keuroghlian A, Ledesma K, Lizcano D, Lozano C, Montenegro 0, Neris N, Noss A, Palacio Vieira J, Paviolo A, Perovic P, Portillo H, Radachowsky J, Reyna-Hurtado R, Rodriguez Ortiz J, Salas L, Sarmiento Dueñas A, Sarria Perea JA, Schiaffino K, de Thoisy B, Tobler M, Utreras V, Varela D, Wallace R, \& Zapata Rios G. 2009. El Destino de los Arquitectos de los Bosques Neotropicales: Evaluación de la Distribución y el Estado de Conservación de los Pecaries Labiados y los Tapires de Tierras Bajas. Pigs, Peccaries and Hippos Specialist Group (IUCN/SSC), Tapir Specalist Group (IUCN/SSC), Wildlife Conservation Society Wildlife Trust.

- Trujillo F, van Damme P \& Usma J (Editors). 2010. The Action Plan for South American River Dolphins 2010- 
2020. WWF, FuncaciónOmacha, WDS, WDCS, Solamac. Bogotá, D.C., Colombia. 249p.

- United Nations Development Programme. 2010. Perspectivas del Medio Ambiente: América Latina y el Caribe. GEO ALC 3. pp 94.

- Utreras, V. \& Pinos, L. 2003. Camera trap use for studying giant otters (Pteronura brasiliensis) in the Yasuní Biosphere Reserve, Ecuadorian Amazon. IUCN Otter Specialist Group Bulletin 20(2).

- Van Damme P, Wallace R, Swaenepoel K, Painter L, Ten S, Taber A, Jimenes RG, Saravia I, Fraser A \& Vargas J. 2002. Distribution and population status of the giant otter Pteronura brasiliensis in Bolivia. Otter Specialist Group Bulletin 19(2).

- Wallace R, Gómez, H, Porcel Z \& Rumiz D. 2010. Ecología y Conservación de los Mamíferos Medianos y Grandes de Bolivia. Fundación Simón I Patiño, Santa Cruz de la Sierra, Bolivia.

- Wallace R \& M Siles. 2011. Chapter: Desarrollando un programa de monitoreo transfronterizo de amenazas y especies paisaje en el Gran Paisaje Madidi-Tambopata en Bolivia y Perú. In book: Memorias de Ponencias del Congreso sobre Areas Protegidas Fronterizas. Copan Ruinas, Departamento de Copan, Republica de Honduras (pp.16-26).

- Wallace R, Reinaga A, Siles T, Baiker J, Goldstein I, RíosUzeda $B$, Van Horn $R$, Vargas $R$, Vélez-Liendo $X$, Acosta L, Albarracín V, Amanzo J, De La Torre P, Domic E, Enciso M, Flores C, Kuroiwa A, Leite-Pitman R, Noyce K, Paisley S, Peña B, Plenge H, Rojas Vera Pinto R, Tapia T \& Vela H. 2014. Andean Bear Priority Conservatiin Units in Bolivia and Peru. Wildlife Conservation Society, Centro de Biodiversidad y Genética de la Universidad Mayor de San Simón de Bolivia, Universidad Cayetano Heredia de Perú and Antwerpen University of Belgium. La Paz, Bolivia. 80p.

- Wallace RB, Ayala G, Bernal Hoverud N, Ticona H, Viscarra M. Submitted.A preliminary checklist of medium and large sized mammals for Madidi National Park and Natural Area of Integrated Management, Bolivia. Checklist.

- Wallace, R., Torrico, O., Porcel, Z. \& Domic, E. 2020. Terrestrial Vertebrate Biodiversity in Protected Areas and Indigenous Territories of the Amazon Basin. WCS. La Paz, Bolivia.

- Wallace, R.B., A. Reinaga, N. Piland, R. Piana, H.Vargas, R. E. Zegarra, P. Alarcón, S. Alvarado, J. Álvarez, F. Angulo, V. Astore, F. Ciri, J. Cisneros, C. Cóndor, V. Escobar, M. Funes, J. Gálvez-Durand, C. Gargiulo, S. Gordillo, J. Heredia, S. Kohn, A. Kusch, S. Lambertucci, D. Méndez, R. Morales, A. More, A. Naveda-Rodríguez, D. Oehler, A. Ortega, 0. Ospina, J. A. Otero, F. Sáenz-Jiménez, C. Silva, C. Silva, R. Vento, F.G. Wiemeier, G. Zapata-Ríos \& L. Zurita. 2020. Protegiendo el Símbolo de los Andes: Un Ejercicio de Priorización a lo Largo del Rango del Cóndor Andino (Vultur gryphus). Wildlife Conservation Society, La Paz, Bolivia,196 p.

- Wilson \& Reeder's Mammal Species of the World Third Edition. <https://www.departments.bucknell. edu/biology/resources/msw3/>. Bucknell University. Pennsylvania, USA. Accessed 18 oct 2016

- Wright SJ. 2010. The future of tropical forest. Annals of the New York Academy of Sciences 1195:1-27.

- Young BE, Josse C, Stern M, Vasconez S, Olander J, Sanchez de Lozada A, Zador M, Smyth R, Comer P, Moull K, Echavarría M, Hak J. 2015. Hotspot de Biodiversidad de los Andes Tropicales. NatureServe \& EcoDecisión. Critical Ecosystem Partnership Fund.

- Zambrana V,Van Dame P, Becerra P \& Gonzáles Juménez R. 2009. Pteronura brasiliensis. Mamíferos. Pp. 475476. In: Libro Rojo de la Fauna Silvestre de Vertebrados Bolivia. Ministerio de Medio Ambiente y Agua, La Paz, Bolivia. 



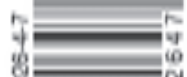

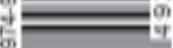

\%

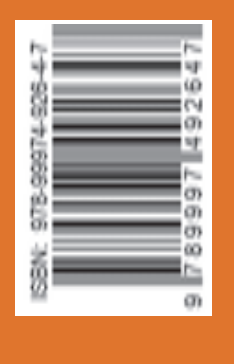

क्ञ

.

.
(1) 